\title{
A tela do padre Bourel: percursos de uma pintura
}

The painting of Father Bourel: paths of a painting

https://doi.org/10.1590/1982-02672021v29e23

\section{MARIA EMILIA MONTEIRO PORTO'}

https://orcid.org/0000-0002-1732-3362

Universidade Federal do Rio Grande do Norte / Natal, RN, Brasil

RESUMO: Estudo sobre a tela A morte do padre Filipe Bourel, pintura a óleo anônima que alude a uma missão jesuítica organizada entre os indígenas da nação Paiacu no final do século XVII, realizada na "Escola Portuguesa do século XVIII". Foi parte de uma grande encomenda litúrgica e devota para ornamentar as igrejas erigidas com a expansão missionária pelas Capitanias do Norte. Remete-se à tradição barroca e segue o modelo de representação da morte de São Francisco Xavier na praia de Goa. Ao aplicarmos o método biográfico no estudo da imagem, acompanhamos o trânsito da pintura entre sua provável origem em uma oficina confessional, seu papel ornamental e devocional em uma igreja periférica do Império Português, os circuitos de colecionadores e leilões de arte, e suas formas de recepção na cultura contemporânea.

PALAVRAS-CHAVE: Pintura. Século XVIII. Barroco Jesuítico. Rio Grande do Norte.

ABSTRACT: This is a study on painting Fr. Filipe Bourel's Death (A Morte do Padre Filipe Bourel), an anonymous oil painting that alludes to an organized Jesuit mission among the Paiacu nation natives at the end of the $17^{\text {th }}$ century, belonging to the "1 $8^{\text {th }}$ Century Portuguese School". Possibly the painting was part of a great liturgical and devotional commission to ornament the churches erected during the Jesuit missionary expansion by the Northern Captaincies. It refers to

\begin{abstract}
1. Doutora em História pela Universidade de Salamanca. Professora titular da Universidade Federal do Rio Grande do Norte (UFRN), Departamento de História. Artigo concluído em estágio de pós-doutorado realizado na Universidade Pablo de Olavide, Sevilha, em 2019. E-mail: <mariaporto2@yahoo.com.br>.
\end{abstract}


the Baroque tradition and follows the model of representation of Saint Francis Xavier's death on the beaches of Goa. By applying the biographical method in the image analysis, the text shows the transit of this painting from its probable origin in a confessional workshop, its ornamental and devotional role in a peripheral church of the Portuguese empire, and from there to the circuits of collectors and art auctions until their forms reception in contemporary culture.

KEYWORDS: Painting. $18^{\text {th }}$ Century. Jesuit Baroque. Rio Grande do Norte. 
A morte do Padre Filipe Bourel é um registro visual do período colonial que tem a região do Apodi como referente. De autoria anônima, a pintura a óleo alude a uma missão jesuítica organizada entre os indígenas da nação Paiacu no final do século XVII, realizada em uma vaga "Escola Portuguesa do século XVIII", como indica o Catálogo do Museu de Belas Artes do Rio de Janeiro, que a mantém em seu acervo: "Morte do Padre Filipe Bourel / século XVIII / óleo s/ tela / sem assinatura / 1 10,5 × 133,5 cm / tombo 10 523". Museu Nacional de Belas Artes, Rio de Janeiro $10523 .^{2}$

Supomos que teria sido pintada em algum momento entre a notícia da morte do padre, em 1709, e 1757, quando Dom Domingos de Loreto Couto, presbítero professo da Ordem do Príncipe dos Patriarcas de São Bento, natural do Recife e Visitador Geral do Bispado de Pernambuco, faz referência em sua crônica, Desagravos do Brasil e glórias de Pernambuco, de 1757, a uma pintura avistada na capela do Apodi que representava o padre Felipe Bourel (1659-1709) em outra situação, curando uma criança indígena, tela cujo paradeiro é desconhecido. Ainda que não seja a mesma tela, a identidade temática e o lugar de exposição parecem indicar que poderiam ser pinturas emparelhadas - a do milagre e a de sua morte -, evidenciando uma mesma procedência. ${ }^{3}$

Na História da Companhia de Jesus no Brasil, publicada entre 1938 e 1950, Serafim Leite se refere ao relato de Loreto Couto. No entanto, a aparição pública da tela se deu efetivamente apenas em 1983, quando foi doada pela viúva do embaixador Afrânio de Mello Franco, Gemina Pereira de Mello Franco (falecida em 1988), à raiz do Projeto Embaixador Afrânio de Mello Franco Filho, coordenado pelo crítico de arte Umberto Cosentino. ${ }^{4}$ Desde então encontra-se no Museu Nacional de Belas Artes no Rio de Janeiro, mas não faz parte da mostra permanente. Válter de Brito Guerra (1923-2002) publicou na terceira edição de seu livro Apodi, no passado e no presente, da Coleção Mossoroense, uma reprodução fotográfica da tela e um capítulo escrito por Olavo de Medeiros Filho, historiador e pesquisador do Instituto Histórico e Geográfico do Rio Grande do Norte (IHGRN), no qual descreve a tela e as circunstâncias de sua descoberta, ocorrida por meio dos círculos de contatos em torno de uma instituição de memória como é o $H G R N$, que recebeu uma cópia da referida tela, com tamanho de $74 \times 62 \mathrm{~cm} .{ }^{5}$ Assim, a tela começou a se integrar também às redes mais amplas de ensino, cultura e política do Apodi. Olavo de Medeiros Filho republicou seu artigo no caderno de cultura do jornal local, $\bigcirc$ Poti, em 1993. Em artigo, Jorge
3. Couto (1904, p. 217, 350351).

4. "Quatro telas, sendo duas atribuídas a Johann Moritz Rugendas (Vista do bairro do Catete e Vista do Litoral da Bahia, século XIX), duas do pintor argentino Martin Borneo (1829-1915), representando o Jardim Botânico e datadas de 1880 e uma coleção de jades e pedras duras chinesas, com cerca de 40 peças, pertencentes à coleção da Embaixatriz Gemina Pereira de Mello Franco, foram por ela doados ao $\mathrm{MN}$ BA. Com essas obras, a Embaixatriz inaugurou em sua residência o Projeto Embaixador Afranio de Mello Franco Filho. [...]. As telas de Rugendas e Borneo e os jades e pedras chinesas, acrescidos da tela A Morte do Padre Bourel, da Escola Portuguesa do início do século XVIII, recentemente doada ao MNBA pela Embaixatriz [...] são um exemplo de como se pode contribuir para o engrandecimento da memória artística brasileira" (SOUZA, 1983, p. 8).

5. Guerra (1995, p. 26-29). 
Coli, historiador da arte ligado ao Museu Nacional de Belas Artes do Rio de Janeiro e à Universidade de Campinas (Unicamp), analisou a iconologia da pintura, ocupando-se de seu lugar como obra de arte e ampliando sua visualidade.

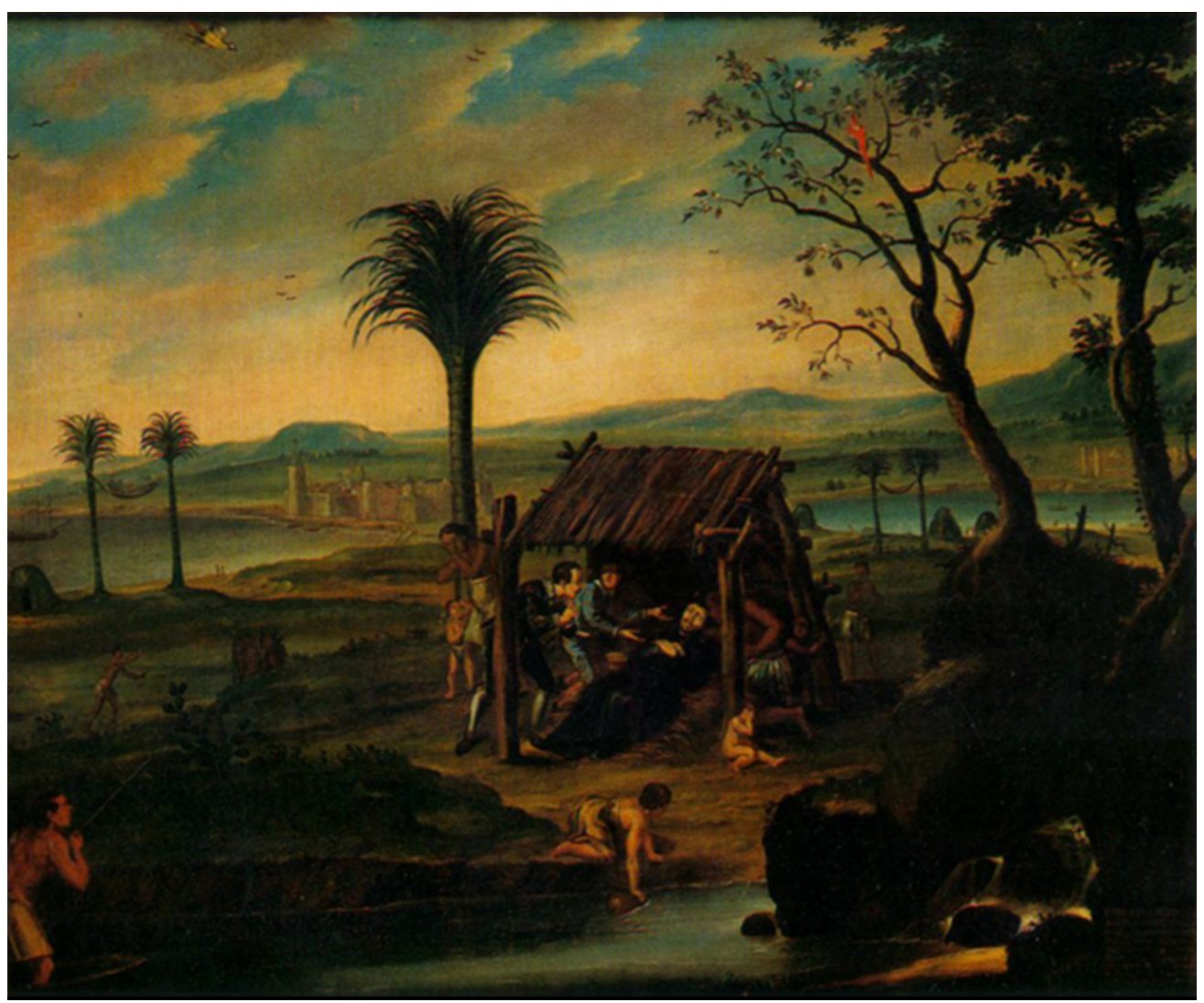

Figura 1 - Autor desconhecido. Morte do padre Filipe Bourel, 1701/1800, óleo sobre tela, 1 10,5 $\times 133,5 \mathrm{~cm}$. Sem assinatura. Coleção Museu Nacional de Belas Artes/lbram/Ministério do Turismo. Fonte: Foto do Acervo do Museu Nacional de Belas Artes. ${ }^{6}$

A tela é tomada pela figuração da morte de Felipe Bourel (1659-1709) (Figura 1). No centro, sob uma cobertura rústica e uma cama de palha, encontrase o religioso moribundo, com um olhar perdido, braços cruzados sobre o peito, vestido com o hábito preto dos jesuítas. Esse é o ponto de perspectiva que organiza a composição. Sob a cabana em torno do padre há algumas pessoas: à esquerda, dois homens brancos muito bem trajados, ao modo europeu, um de azul e outro de preto, com seus respectivos brocados. À direita, um indígena adulto vestido com um saiote de penas. Junto a ele, abraçado à coluna traseira que sustenta a cabana, uma criança indígena, e outra menor, no chão, recostada na coluna dianteira. No lado esquerdo da tela, muito próximos à cabana e 
diante de uma palmeira, encontram-se uma criança e um adulto indígenas vestidos com panos de algodão. Do lado direito da cabana do padre, um indígena vestido de saiote de penas se aproxima da cena central. No lado esquerdo outro indígena que parece vestido de panos de algodão dirige-se agilmente a esse mesmo ponto. Ao pé da tela, um pouco à frente da cobertura rústica, há uma massa de água que emana de um espaço dourado e luminoso entre pedras e trepadeiras que sobem e se enredam nas árvores que estão acima dela, estendendo-se ao lado esquerdo da tela. Desse ponto assoma um indígena vestido de panos de algodão em uma canoa, munido de um bastão ao modo de remo, que parece dirigir-se à cobertura onde está o padre. Na margem do rio próxima à cabana vemos um indígena agachado que recolhe água com um cabaço, talvez para oferecê-la ao padre moribundo. No lado direito dessa cena há duas árvores de grande porte cujas raízes parecem nascer das pedras e do emaranhado de trepadeiras: uma, mais alta e frondosa; a outra, mais baixa e florescente, em cujos galhos está pousado um papagaio, ou uma arara. Nessa cena, todos que estão próximos ao padre choram ou têm feições de tristeza, afetados por sua agonia e iminente morte. Alguém teria dado a notícia, porque o homem da canoa, por exemplo, parece aproximar-se pelo rio consciente de algo que vai mal, pois olha ansioso para a cena. Alguém teria avisado ao povo que o padre morrera ou já estaria enfermo e por isso todos esperavam uma má notícia? Há dois movimentos de pessoas nas cenas na tela: o padre agonizante e as pessoas que o acompanhavam ou que dele se aproximavam, dando-se conta do sucesso, e, mais afastados da cena central, quase imperceptíveis, pessoas entregues a seus labores, indicadas pelas silhuetas. À esquerda, próximo a duas palmeiras, vemos indígenas em atividade de pastoreio, deduzida pelos dois bois figurados nesse espaço, e, à direita, outros trabalhando em uma plantação, indicando serem terras de pasto e plantio. $O$ terreno ao redor da cabana é de vegetação baixa, onde se destacam um cacto, uma palmeira e as árvores mencionadas. Ao longe vemos moradias indígenas de formas triangulares e arredondadas na parte superior. Dependurada em uma altura impossível entre duas palmeiras está uma rede, figuração que se repete nos dois lados da tela e que não corresponde aos hábitos da cultura indígena, isto é, repousar em redes tão altas. Um pouco acima vê-se, à esquerda, uma segunda massa de água na qual há uma grande embarcação e algumas canoas na margem oposta. Ao fundo há uma grande cidade fortificada, com seus torreões, casario e campanários, que parece se estender para o fundo da cena e por trás dela, aparentemente uma vegetação densa. À direita, na mesma linha, há uma terceira massa de água em cuja margem vemos pessoas em seus labores e uma canoa 
passando. Em sua outra margem há outra grande construção com duas torres e quatro cúpulas que ficam como que emolduradas pelos troncos das duas árvores mencionadas. Ao fundo dessa fortificação se avista uma linha de arvoredo. A impressão de espelho d'água criada pelas águas, recorrente na paisagem clássica, provoca efeitos de luminosidade ou reflexos.

A parte superior da tela descortina uma ampla paisagem. Nela vemos três elevações rochosas: a da esquerda é menor do que as demais e parece mais próxima da fortificação. A do meio é mais ampla e distante. A terceira é uma grande serra, mais alta e consistente do que as anteriores. $\bigcirc$ céu apresenta umas nuvens densas e um pássaro branco voando na altura delas. Há também outros pássaros, ainda que menores ou voando mais alto. Pousada na árvore florescente está uma arara ou papagaio vermelho. $\bigcirc$ horizonte é alto. As cores, que variam entre tons azuis e amarelos crepusculares, provocam uma perspectiva atmosférica, com uma luminosidade que se projeta no céu, criando um efeito de brisa fresca no ar. A variação do tamanho das figuras cria a impressão de uma vasta paisagem.

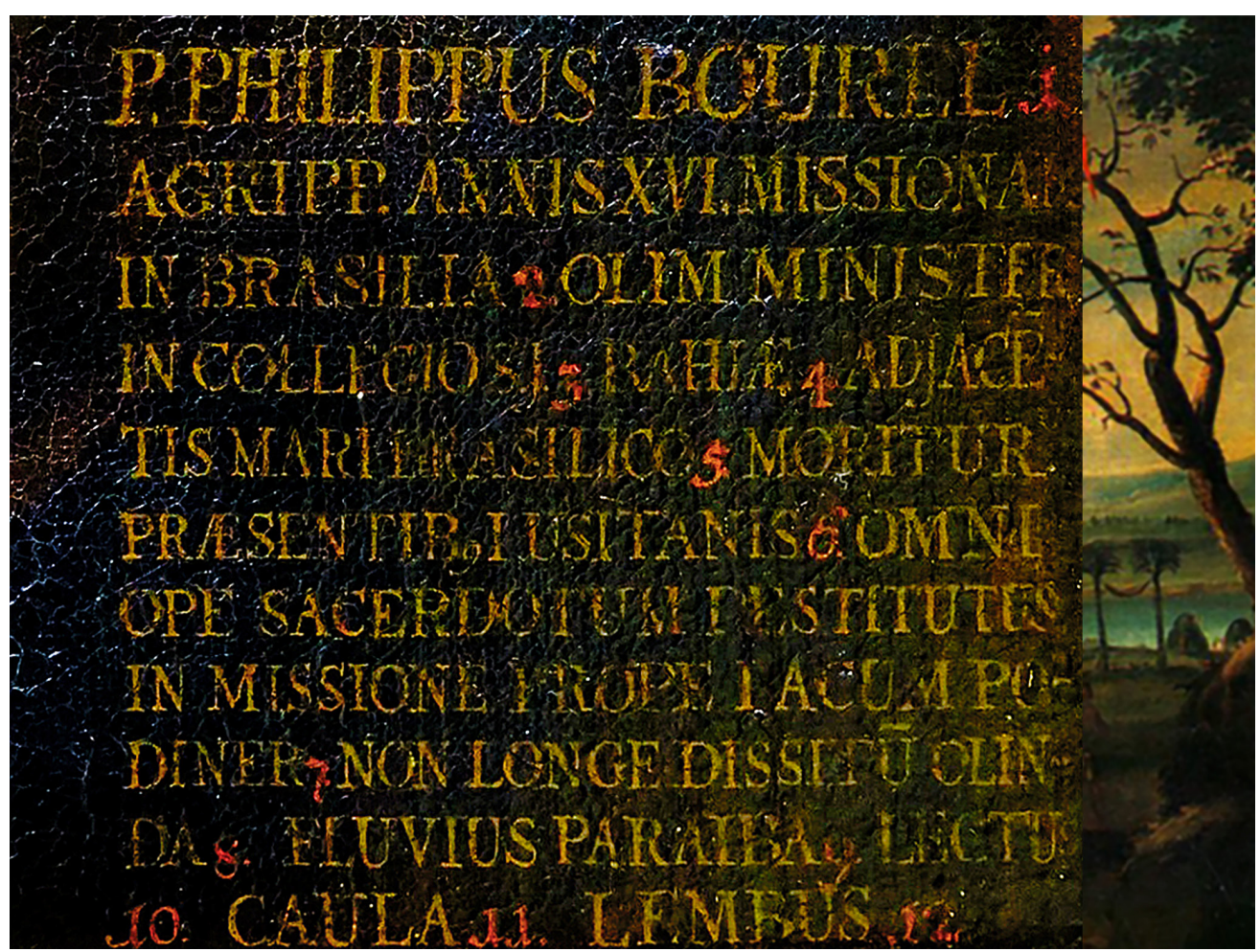

Figura 2 - Inscrição em latim no canto inferior direito da tela. 
No lado inferior direito da tela há uma inscrição em latim (Figura 2):

\section{P. PHILIPPUS BOUREL 1}

AGRIPP. ANNIS XVI MISSIONAR

IN BRASILIA 2 OLIM MINISTER

IN COLlEGIO S. J. 3 BAHIAE 4 ADJACE

TIS MARI BRASILICO 5 MORITUR

PRAESENTIBUS I LUSITANIS 6 OMNI

OPE SACERDOTUM DESTITUTUS

IN MISSIONE PROPE LACU PO

DINER 7 NON LONGE DISSITU OLIN

DA 8 FLUVIUS PARAIBA 9 LECTU

10 CAULA 11 LEMBUS 12 BRASILIORUM 13.
7. Há diferenças nas traduções propostas para essa legenda. No ponto 6 , os professores José Melquíades de Macedo e Waldson Pinheiro, intelectuais ligados ao Instituto Histórico do Rio Grande do Norte, traduziram por "tendo desempenhado todas as funções sacerdotais na missão junto ao lago do Apodi", conforme publicado por Olavo de Medeiros Filho (1993). Quanto ao ponto 2, consta no catálogo do $\mathrm{Mu}-$ seu Nacional de Belas Artes como: "[...] nascido nos anos mil e seiscentos". Bourel, de fato, nasceu no Seiscentos, em 1659, mas 16 anos foi o tempo total em que esteve nas missões do Brasil, entre 1693 e 1709 , parecendo ser esta, portanto, informação mais exata que a tela teria pretendido veicular (SOUZA, 1985, p. 238).

\section{Em português: ${ }^{7}$}

Padre Felipe Bourel 1,

de Agripi. Por 16 anos missionário

em terras do Brasil 2 antes ministro

no Colegio da Companhia de Jesus 3 na Bahia 4

junto ao mar brasileiro 5 morre

em presença de Portugueses 6 de toda

asistencia sacerdotal desprovido

na missão próxima ao lago do Apodi 7 não muito longe de Olin

da 8 Rio Paraíba 9 em [seu] leito

10 cabana 11 embarcação 12 de Brasileros 13. 


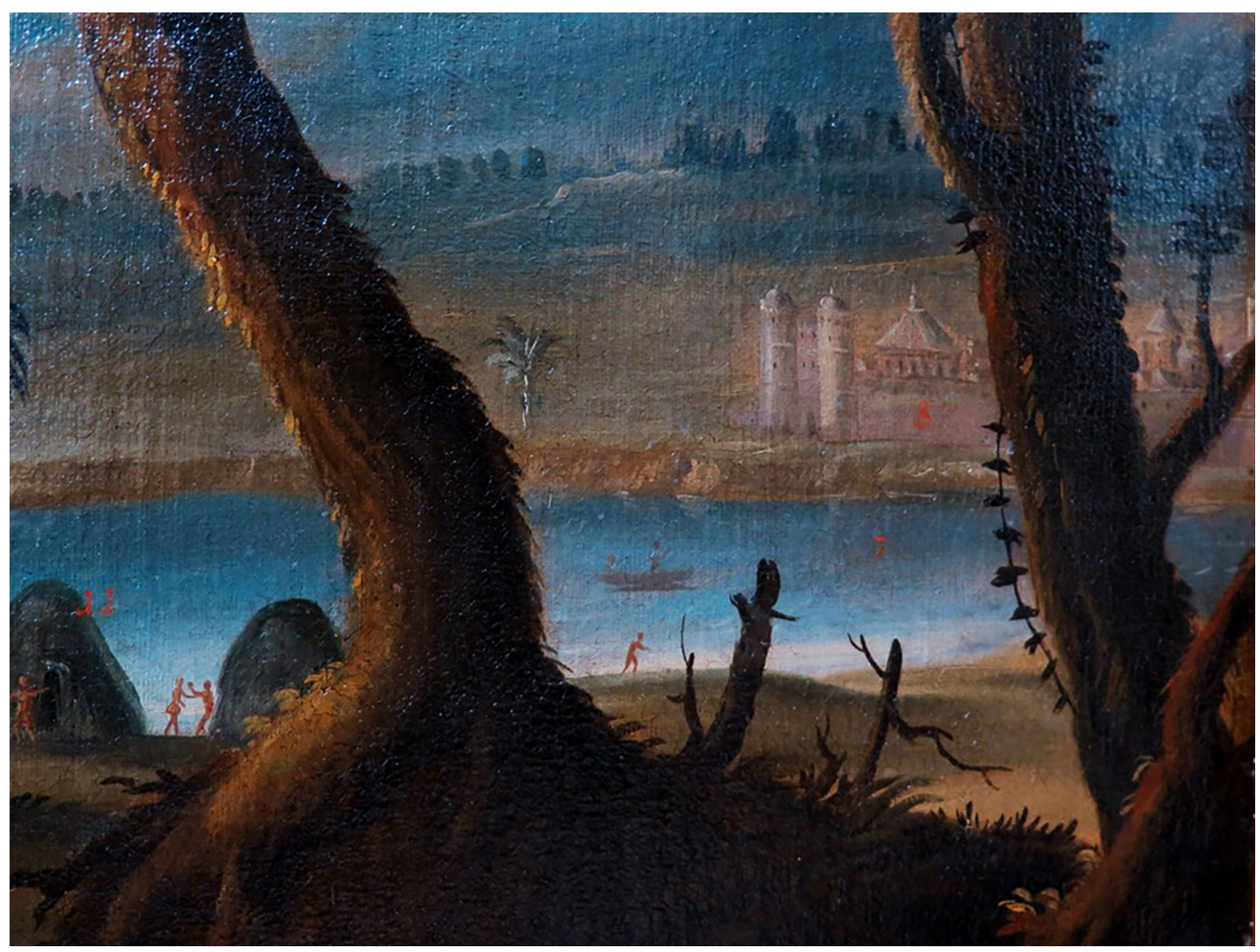

Figura 3 - Detalhe da numeração 7, 8 e 1 1, indicando os lugares da tela.

Texto enigmático e memorial liga-se ao figurado por meio de uma numeração (Figura 3) que sugere ao espectador um circuito entre os lugares que compõem a vida do padre. Seguindo a numeração da tela em suas quase ilegíveis marcas de tinta vermelha, e levantando hipóteses de natureza iconográfica, essas são as referências acerca dos lugares assinalados.

"Padre Felipe Bourel 1", o padre biografado. Com "[...] de Agripi. Por 16 anos missionário em terras do Brasil 2", indica-se que ele nasceu em Colônia, cidade burguesa às margens do rio Reno, representativa do poder católico no contexto das lutas religiosas entre protestantes e católicos do século XVI e da tradição jesuítica, pois quando era cidade romana chamava-se Colônia Agripina. Bourel saiu de Colônia em 1693, vindo como missionário para o Brasil. A passagem "[...] antes ministro no Colégio da Companhia de Jesus 3" pode indicar seu pertencimento aos quadros da Companhia entre Colônia e Coimbra antes de vir para o Brasil. $\bigcirc$ trecho "[...] na Bahia 4" indica o Colégio da Bahia, primeira base de difusão missionária jesuítica no Brasil, desde 1549, onde Bourel atuou como missionário, superior de aldeamentos entre os índios do grupo Rodela, os Tuxá, de filiação linguística desconhecida, sendo mestre de noviços na ocasião da expulsão dos jesuítas das missões a oeste do rio São Francisco, o "sertão de Dentro" ou "sertão de Rodelas", 
pelos fazendeiros em 1688. ${ }^{8}$ Trata-se de uma referência ambígua devido à figuração da construção, que efetivamente se parece muito com o modelo medieval e europeu de construções e de cidades, tendo sido tomada por Olavo de Medeiros Filho como um castelo da cidade de Colônia, onde nasceu e viveu como estudante do Colégio da Companhia de Jesus. $O$ pintor da tela pode ter efetivamente jogado com a possibilidade de uma dupla leitura da imagem: como Bahia ou como Colônia. Nesse caso, o castelo figurado na tela seria o Castelo de Godesburg, entre Bonn e Colônia, destruído entre novembro e dezembro de 1583 ? Isto é, tratar-se-ia de uma forma de mencionar o primeiro grande sucesso da Contrarreforma na Alemanha? Ou, mais provável, o Colégio dos Jesuítas em Colônia? Com "[...] junto ao mar brasileiro 5" quer-se indicar o porto da Bahia, de onde partiam e chegavam as embarcações atlânticas que ligavam Europa e América. $\bigcirc$ trecho "[...] morre em presença de Portugueses 6 " indica os dois homens vestidos à moda europeia, o que corresponderia ao escasso apoio que essas missões receberam dos moradores fazendeiros e curraleiros da região, que se opunham sistematicamente à autoridade jesuítica em relação à políitica missionária do governo colonial. Poderia ser uma referência ao episódio no qual alguns moradores da região impediram que se queimasse a residência dos padres durante um ataque à aldeia. Em "[...] de toda assistência sacerdotal desprovido na missão próxima ao lago do Apodi 7" indica-se o martírio do padre por não ter recebido os últimos sacramentos, pois seu companheiro de missão, o padre Manuel Dinis ou o padre Bonifácio Teixeira, falecido em 1712, não estava na aldeia. ${ }^{9}$ A expressão "[...] não muito longe de Olinda 8" remete-se à cidade na qual estava o Colégio de Olinda, que, ao lado do Colégio da Bahia, foi uma das mais importantes bases jesúíticas da fronteira missionária nas capitanias do norte, responsável pela consolidação da expansão leste-oeste e base da Companhia de Jesus mais próxima do Rio Grande e do então remoto Apodi. A indicação do "Rio Paraíba 9" poderia ser uma referência à conquista da Paraíba em 1585, começo da expansão ocasionada inicialmente pelos padres do Colégio dos jesuítas na cidade de Olinda. Pode indicar também a aldeia de Urutagui, na capitania da Paraíba, para onde os padres Ginzl e Vicente Vieira, outros dos companheiros de Bourel nessas missões do sertão, levaram um grupo de Paiacus sobreviventes dos massacres para ali aldeá-los. A passagem "[...] em [seu] leito 10" indica as redes dependuradas nas palmeiras, nas quais os indígenas dormiam. Com "[...] cabana 11 "apontam-se as habitações indígenas, as ocas, e com "[...] embarcação 12" indica-se a canoa, seu meio de transporte fluvial. O trecho "[...] de Brasileiros 13" certamente se refere ao indígena que está na canoa na parte inferior da tela, tanto por ser a representação mais destacada quanto por causa de uma nódoa branca que poderia ser esse número desgastado. A diferença na vestimenta dos indígenas
8. Antes da instalação da capitania do Piauí, em 1718, desmembrando-se do estado do Maranhão, toda a região a oeste do rio São Francisco era conhecida por "sertão de Dentro" ou "sertão de Rodelas".

9. Leite (2004a, p. 375-376). 
figurados - uns de saias de penas e outros com o típico pano de algodão produzido nas missões - pode indicar o nível de adaptação cultural, uma vez que se tratava de uma missão que ao longo de sua vigência recebeu sobreviventes de massacres que mantinham seus hábitos originários, convivendo com os que se encontravam em processo de aculturação aos modos dos padres. As figuras narrativas irradiam a partir do centro da pintura - a cabana do padre na aldeia do Apodi - e se abrem a uma multiplicidade de cenas descritivas que compõem uma narrativa de natureza religiosa.

Os dados históricos que se seguem ocupam um lugar especial nesse estudo, uma vez que o pathos, energia interna e potência transgressora da tela, estaria no evento singular que ela registra: a morte de um missionário no Apodi, que, figurado de forma devota e singela, leva o receptor da mensagem a experimentar proximidade e empatia com o que the afeta. É um tropos de santidade e martírio que adquire identidade política e espacial quando se remete à legenda. Essa afecção se apresenta tanto na relação entre uma região e a tradição culta a que pertence a tela, valorizando seu lugar em uma geopolítica nacional, quanto à questão indígena, que, pelas conexões que estabelece com a experiência histórica na região, valoriza o problema da cidadania de minorias étnicas na política brasileira. É nesse sentido que a tela é recriada e revivida nos festejos natalinos no município do Apodi, Rio Grande do Norte. $\bigcirc$ que é comovente na tela mantém seu sentido no contexto diverso em que se apresenta.

De modo imediato, a pintura é representativa do movimento missionário que se difundiu fortemente a partir da primeira modernidade no século XVI. A missão do Apodi começou como resultado de uma nova política do governo colonial, uma política de controle do conjunto dos levantes que ocorriam desde a região do Recôncavo Baiano, configurado na historiografia das rebeliões indígenas coloniais como Confederação dos Tapuias ou Guerra dos Bárbaros, controlada em seu conjunto por volta de $1713.1{ }^{10}$ Resultou da pressão dos sertanistas paulistas sobre os territórios indígenas, que teve início por volta de 1650, dirigindo-se para o vale do rio São Francisco, mesma ocasião em que a população da capitania do Rio Grande iniciava sua expansão para oeste, alcançando outra onda povoadora que irradiava do vale do Jaguaribe, no Ceará, para leste. Estimulados pelo fim da ocupação holandesa (1 630-1 654), essa onda povoadora encontrou os territórios tradicionais indígenas e neles estabeleceu currais de gado.

O Apodi era um território de transição de povos Tapuia do Nordeste brasileiro. Como povos semissedentários ou seminômades, compartilhavam formas móveis de agricultura e de agrupamento social, deslocando-se com regularidade dentro de um território definido, obedecendo ao ciclo de caça e coleta de alimentos. Acercavam-se do litoral nos meses de novembro a janeiro para pescar 
e evitar a época de seca no sertão, retornando entre março e abril, época das chuvas. " Pertenceriam a um grupo etnolinguístico isolado, pois não são do grupo Gê, nem do Kariri, e muito menos do grupo Tupi. $\bigcirc$ sítio arqueológico do Lajedo da Soledade, assim como diversas inscrições lapidares encontradas por moradores da região, atesta essa frequência sazonal. ${ }^{12}$ Com a perda de seus territórios, os índios levavam a instabilidade do sertão paras as zonas produtivas e povoadas do litoral, atacando as casas fortes das ribeiras dos rios, povoações, plantações e fazendas de gado, gerando conflitos que alcançaram o Rio Grande entre 1655 a 1679 sob a forma de uma série de levantes isolados que se alastraram entre 1682 e 1684, até que em fevereiro de 1687 a capitania do Rio Grande viveu o que é considerada uma das etapas da Guerra dos Bárbaros, a Guerra do Açu. ${ }^{13}$

Os Tapuia foram enfrentados inicialmente com as milícias formadas pelos moradores, pelo "Terço dos Índios" de Diogo Camarão das aldeias de Natal, pelas tropas pernambucanas e o "Terço dos Negros" de Henrique Dias e, posteriormente, pelas tropas paramilitares dos "Terços dos Paulistas". Em 1697, o então mestre-decampo dos paulistas, Manuel Álvares de Moraes Navarro, solicitou o apoio da fronteira missionária jesuítica para a nova frente de conflitos que se abria nos "sertões de cima" de Pernambuco, com ambas as forças atuando na nova política projetada por volta de 1689: um cinturão de aldeamentos no sertão (e não mais a transferência dos grupos rendidos para aldeamentos do litorall, entre a região do Assu e a serra da Ibiapaba, lugares que correspondem hoje aos estados do Rio Grande do Norte e Ceará, que receberiam os índios rendidos nos ataques, garantindo o povoamento e a segurança do espaço criatório e empurrando as frentes bárbaras progressivamente para o sertão do Ceará. Esse foi o contexto em que o padre Bourel e seu companheiro, João Ginzl, se deslocaram para atender essa fronteira juntando os grupos de Paiacu que se encontravam dispersos pelos matos. A política pactista aplicada pelo Estado português, na qual as missões eram centrais, era precedida por massacres sistemáticos, exploração de inimizades intertribais e criação de situações que os enquadrariam nos decretos de guerra justa de extermínio.

As notícias da missão entre 1706 e 1709 indicam que prosseguia o pantanoso ambiente jurídico colonial no qual as missões continuavam fornecendo índios para acompanhar a guerra que ocorria nas fronteiras de São Luiz do Maranhão. A persistência do seminomadismo nas ocasionais e precárias regularizações das terras que thes eram assignadas facilitou as invasões dos moradores em suas ausências temporárias. A opção dos povos Tapuia do sertão era render-se e integrar-se a um aldeamento no qual poderiam aprender algum ofício, prestar serviços na agricultura, nas casas e nas guerras de conquista, integrados como índios aliados; ou, por fim, fugir para oeste, basicamente a serra da lbiapaba, quilombo afro-ameríndio do qual,
11. O sertão corresponde à faixa irregular localizada na região sublitorânea que compreendia as zonas secas e as ribeiras dos rios Jaguaribe, Apodi, Açu, Piranhas, Sabugi e Seridó, com vegetação de caatinga e espécies de plantas de pequeno porte adaptadas a longos períodos secos e grandes matas de carnaúba. $O$ aventureiro e morador do Rio Grande no século XVII, Roulox Baro, chamou essa região de "País dos Tapuias". A Chapada do Apodi, especificamente, é composta por terras planas com altitude inferior a cem metros e faz parte de uma zona de transição entre o Planalto da Borborema na Paraíba e parte no Rio Grande.

12. Araripe (1857, p. 258), Lockhart e Schwartz (1992), Medeiros Filho (1984), Moreau e Baro (1979), Porto (2001).

13. Os padres Ginzl e Vicente Vieira organizaram a aldeia de N. Sra. da Anunciada, em terras da ribeira do rio Jaguaribe, e Bourel organizou a do Apodi. A do Apodi acolheu inicialmente duzentos sobreviventes de um masacre ocorrido em 1700 e chegou a abrigar cerca de mil indígenas da nação Paiacu, também conhecida como Jaracu, do macrogrupo "Tapuia”, que habitavam a região compreendida entre o rio Açu, na Chapada do Apodi, no Rio Grande do Norte, e o baixo Jaguaribe, no Ceará, e que conheceram os muitos nomes da morte: massacres, êxodo, exílio e a fome, advertida em 1695 pelo secretário do Estado do Brasil, Bernardo Viera Ravasco, irmão do padre Antônio Vieira, pela quase impossibilidade de produzir alimentos em terras ruins e espaço inseguro (PESSOA, 2017). 
14. Motta (1920-1921, p. 4549, 90) e Medeiros Filho (1987).

15. Couto (1904, p. 350). além do padre Antônio Vieira, outros missionários atuantes nas missões do Maranhão nos deixaram relatos, e que conformava a região mais ampla a que a tela se abre, esses "sertões de dentro", que em seu conjunto conformavam uma vasta região chamada por vezes de território de Jaguaribe e outras vezes de Açu, nos confins dos atuais estados do Rio Grande do Norte, Ceará, Piauí e Maranhão. O aldeamento do Apodi teve um melancólico fim de administração jesúíica e de dispersão e retorno dos Paiacu a seus costumes étnicos. $\bigcirc$ padre Bourel, certamente adoecido pelas vicissitudes da missão, morreu em 1709. Por fim, ocorre a ruína do padre Bonifácio Teixeira de Arrifana, outro de seus companheiros de missão, que morre em um ataque de Tapuias nos caminhos do sertão, em 1712. Não foram encontrados dados precisos sobre quem geriu a missão em substituição aos jesuítas até 1725, quando foi reocupada pelos capuchinhos italianos dirigidos pelo frei Prospero de Milão, em 1734. Na pequena povoação que se formou, ergueu-se em 1740, com o frei Fidélis de Padavolis à frente e com a mão de obra dos indígenas, a pequena capela de madeira e barro que teria substituído a capela primitiva da missão. ${ }^{14}$

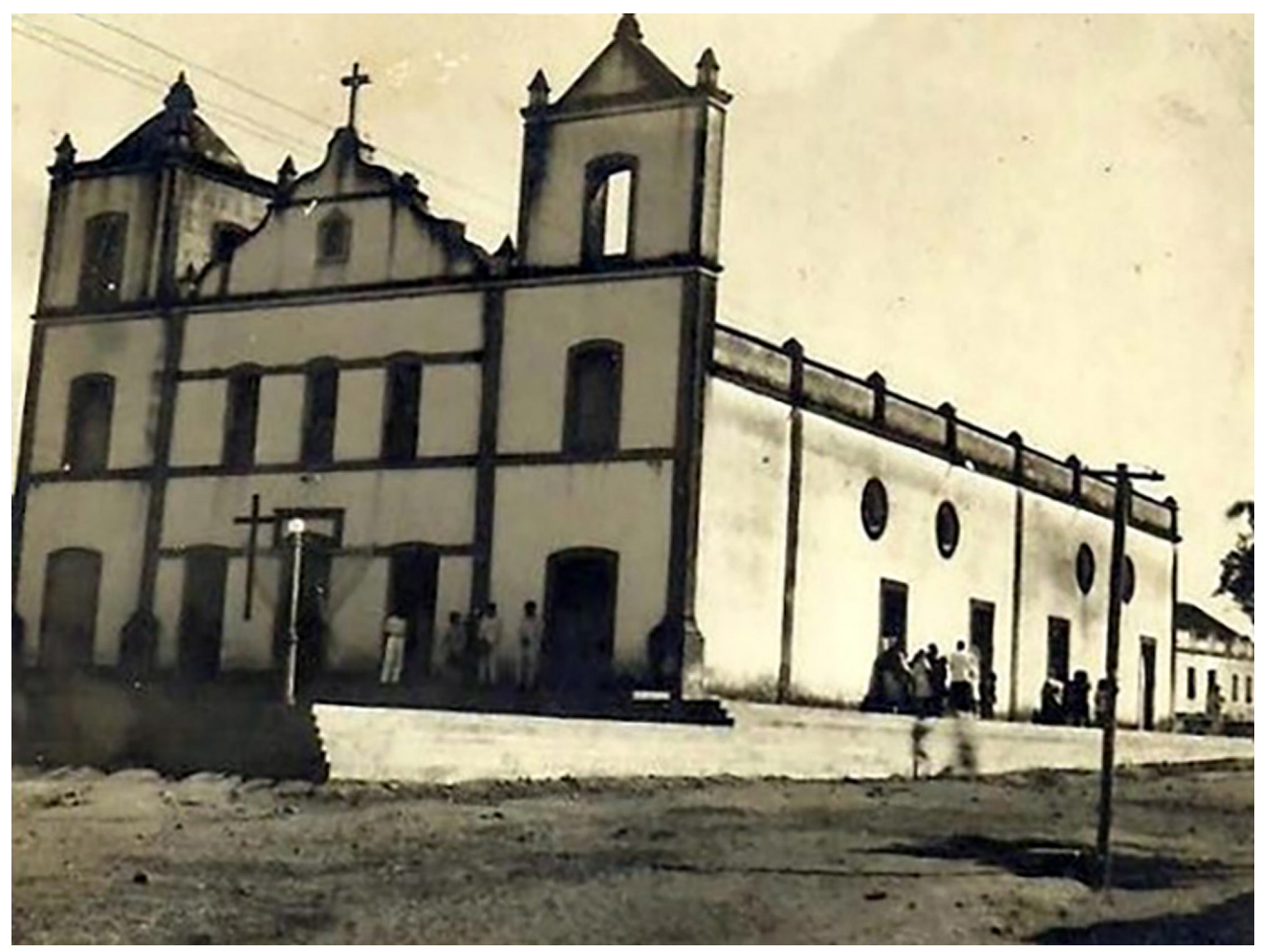

Figura 4 - Igreja-matriz de São João Batista e N. Sra. da Conceição. Fonte: <https://bit. ly/32HgB2u>.

Nessa igreja (Figura 4), Dom Domingos de Loreto Couto avistou em 1757 a pintura que representava o padre Bourel curando uma criança Paiacu. ${ }^{15}$ Aí teriam 
sido dadas condições de visualidade nas quais essas imagens que ensinavam "de forma proveitosa, viva e deliciosa os mistérios da Fé" 16 podiam ser apreciadas. As referências sobre a região indicam certa estabilidade no aldeamento, apesar da tendência negativa da política portuguesa em apoiar as missões.

Em 1759 foi decretada a expulsão da Companhia de Jesus no Brasil e até 1773 cartas pastorais e alvarás completavam o processo de desautorização e confisco de seus bens, dos privilégios e da autoridade de seus membros, tanto espiritual como temporal. Na capitania do Rio Grande suas terras foram adquiridas pelos habitantes mais destacados, especialmente os oficiais da milícia, levando ao fortalecimento da oligarquia brasileira que adquiriu as propriedades mais bem administradas de toda a colônia, como o eram as propriedades jesuíticas. ${ }^{17}$ Uma das reformas políticas do governo pombalino foi adequar os aldeamentos ao modelo urbano de freguesias e vilas, levando a missão à extinção, em 1761 , quando mais de setenta famílias, segundo Nonato Mota, foram transferidas do Apodi para a Vila Nova de Portalegre (desmembrada em 1833 da Vila do Apodi), distantes cerca de $60 \mathrm{~km}$. Em 1766 foi criada a paróquia do Apodi, com seus dois padroeiros, São João Batista e Nossa Senhora da Conceição, cujas imagens vieram da Europa e estão expostas até hoje no altar mor da igreja matriz. Todos os empenhos na integração da região à ordem colonial sugerem a ação dos setores eclesiásticos por meio do bispado de Olinda e Recife, em aliança com os moradores de algum cabedal, e não mais com os setores missionários. ${ }^{18}$

\section{ICONOLOGIA}

Jorge Coli, pesquisador brasileiro da história da arte, realizou a primeira análise rigorosa dessa tela, estabelecendo sua pertinência e suas propriedades. Sua análise iconológica da pintura decifrou os enigmas nela figurados e os padrões de representação em vigor na cultura europeia presentes em pinturas clássicas da história da arte. ${ }^{19}$ A pintura se remete à tradição pictórica do Renascimento, especialmente à tradição barroca dos séculos XVII e XVIII, ao expressar uma nova sensibilidade religiosa inspirada no modelo de imitação da vida de Cristo proposto pela devoção moderna e pelo programa da Contrarreforma católica. Passa-se então da representação do Cristo sereno à do Cristo sofrente, fazendo predominar as figurações cruas e dolorosas que expressam a transitoriedade e precariedade da existência, que comovem mais do que convencem. ${ }^{20}$
16. Praz (1946, p. 226 apud COLI, 2009, p. 126).

17. Salmoral (1990, p. 649).

18. Documentos das visitações inquisitoriais que mostram o controle sobre o comportamento moral da colônia reportam o caso, em 1752, do frei Inácio de Jesus, carmelita reformado da província de Pernambuco, residente na Freguesia do Açu, e do padre José Inácio de Oliveira, da Freguesia de S. João Batista do Apodi, envolvidos em crimes de solicitação e denunciados por mulheres paroquianas. Ou o caso do indígena José Roiz, que foi denunciado em 1760 por portar amuletos com a hóstia, e Pedro Álvares Correia, denunciado em 1765 pelo padre José de Freitas Serrão por portar uma bolsinha no pescoço contendo uma "oração forte" para proteger-se do chumbo e do ferro, que the teria sido dada pelo padre André Sepúlveda, da Freguesia do Apodi, a troco 7 bois (!) (MOTT, 1986). O panfleto do padre Joaquim Pereira, de 1798, apresenta o quadro de desolação da região com a "seca" de 1792 e 1793 (PEREIRA, 1857).

19. Coli, op. cit.

20. Maravall (1997, p. 497520). 
21. Coli, op. cit., p. 111.

22. Ibid., p. 117.

23. Ibid., p. 112.
A qualidade da pintura, segundo Coli, é atestada pelo "equilíbrio entre a cena um pouco recuada, que se destaca sem se impor, e o meio que foi caprichosamente caracterizado". ${ }^{21}$ A força da cor e a profundidade colocam os elementos icônicos em tensão no espaço pictórico, articulando oposições: cév e terra criam a metáfora de ascese da simbologia cristã; a solidão do ermo no qual Bourel morre se opõe às fortificações - o ermitão, que se coloca fora do mundo civilizado -; a delicada floração de uma das árvores indica a fecundidade da fé, que encontra força junto a outra árvore, maior e mais velha, a da tradição. A ave solitária que faz o céu descer expressa o movimento de Deus dirigindo-se aos homens e a palmeira faz a terra subir, expressando o esforço ascético humano em direção a Deus. A morte do padre, em martírio porque privado da extrema unção, se redime pela palmeira, que é metáfora da cruz: é seu renascimento em Cristo, pois "o justo florescerá como a palmeira", ${ }^{22}$ segundo canta o livro dos Salmos 92:12. O modelo arquitetônico das fortificações é o de Vauban, difundido na Europa no século XVII e tema já frequente de pinturas de batalhas. A furna estaria ligada ao ato do batismo e as duas cidades figuradas ao fundo - Bahia e Olinda - poderiam se remeter às duas cidades santas, Jerusalém e Roma, a nova Jerusalém.

Apresentando o problema da expressão local na realização da tela, Coli propõe que a cabana da morte de Bourel, que poderia provocar associações americanistas, tem como modelo a cabana primitiva de Vitrúvio, e não as habitações dos povos ameríndios, com suas coberturas semicilíndricas, sobre as quais já circulavam representações pela Europa desde o século XVI, como as de Hans Staden, André Thévet, Jean de Léry, Guilherme Piso, George Marcgraf, Frans Post ou Albert Eckhout. Do mesmo modo, o papagaio ou arara pode ser sinal dos trópicos, mas não é exclusivo da América, pois, antes disso e assim como o galo, trata-se de um símbolo que alude à Anunciação. No entanto, por estar pousado na árvore mais jovem e florescente, é símbolo do Novo Mundo. Ao anunciar a vinda do Messias, o papagaio associa-se à eloquência e, assim, foi tomado pelos jesuítas como emblema da Companhia de Jesus, visível no afresco de Andrea Pozzo no teto da Igreja de Jesus, em Roma, intitulado Alegoria do trabalho missionário dos jesuítas, no qual a América é figurada como uma índia de cocar colorido, combatendo o paganismo com uma lança, tendo a seu lado o papagaio. A embarcação de brasileiros, ao mesmo tempo que pode expressar uma circunstância local, a dilui por causa da topografia incerta inscrita na tela: Bahia, Paraíba, Rio Grande do Norte, Olinda, ou talvez até Colônia. As evidências dos padrões se estendem às redes figuradas na tela, que poderiam ter sido inspiradas na gravura Figure des brisilians, da obra conhecida como Triomphe de Henry, publicada em Rouen, de 1551, mas com altura exagerada. ${ }^{23}$ 


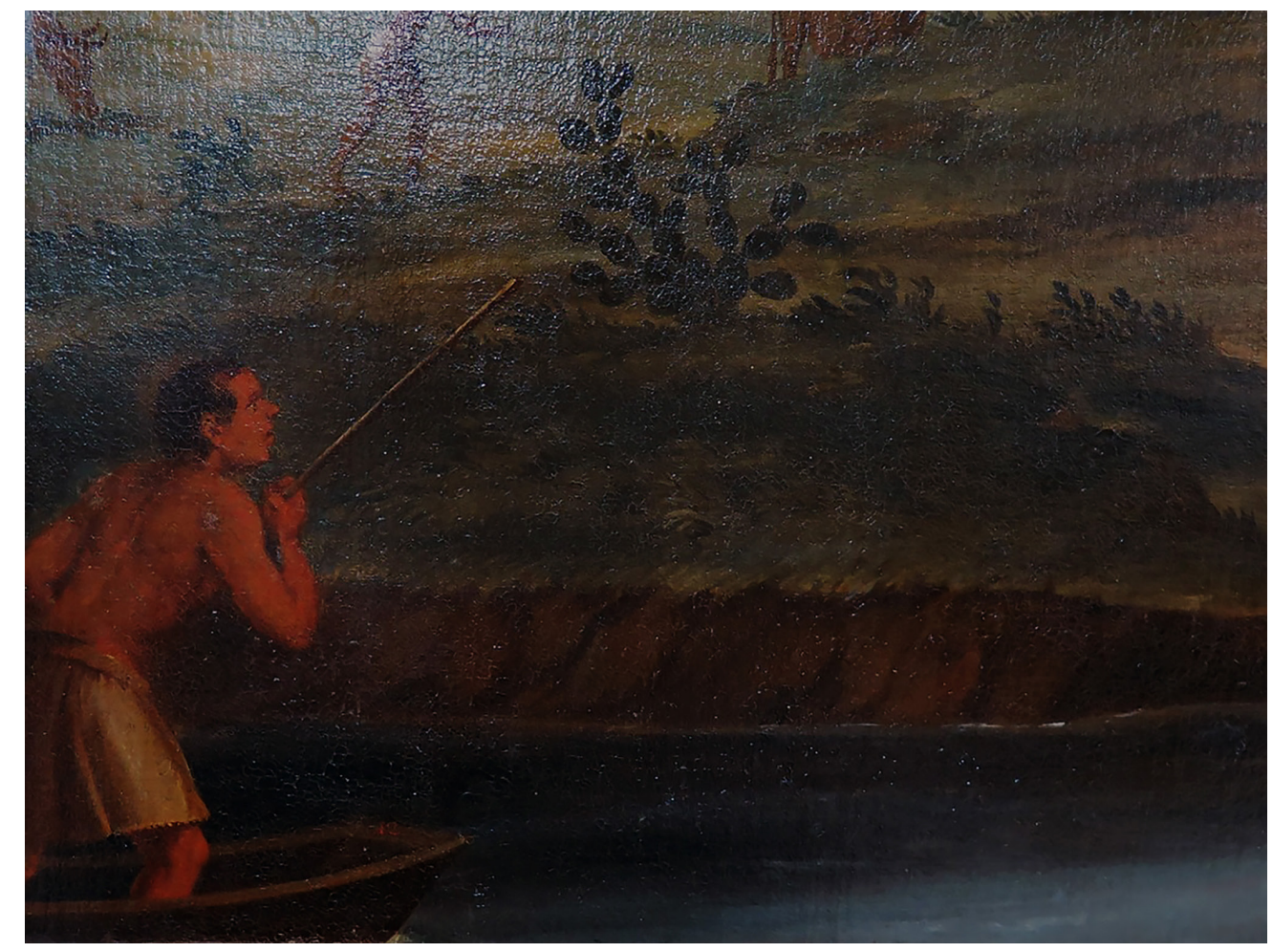

Figura 5 - Detalhe de representação do indígena Paiacu.

Para a representação do Paiacu do Apodi, no canto inferior esquerdo da tela (Figura 5) vemos o caráter de relato etnográfico. E o pintor se mostrou habilidoso: o corpo indígena representado na tela está individualizado e apresenta um perfil do rosto com suas feições e uma expressão de espanto. $\bigcirc$ nível de aculturação está representado nos panos tapa-sexos, mas sem chegar a figurar costumes ocidentais marcantes que comprometam a identificação visual como indígenas. Tampouco há qualquer menção a suas práticas pagãs. Não se trata de uma reunião de clichês sobre a América exótica, mas sim da representação barroca do índio integrado na ordem do humanismo da época. Diferente, por exemplo, da representação objetificadora, como a de Eckhout sobre os Tarairiús, na qual, aliás, vemos alguma semelhança com a representação do indígena Paiacu (Figura 6): o fato de representá-los com maior precisão e detalhe não significou que tenha levado em conta suas diferenças. 


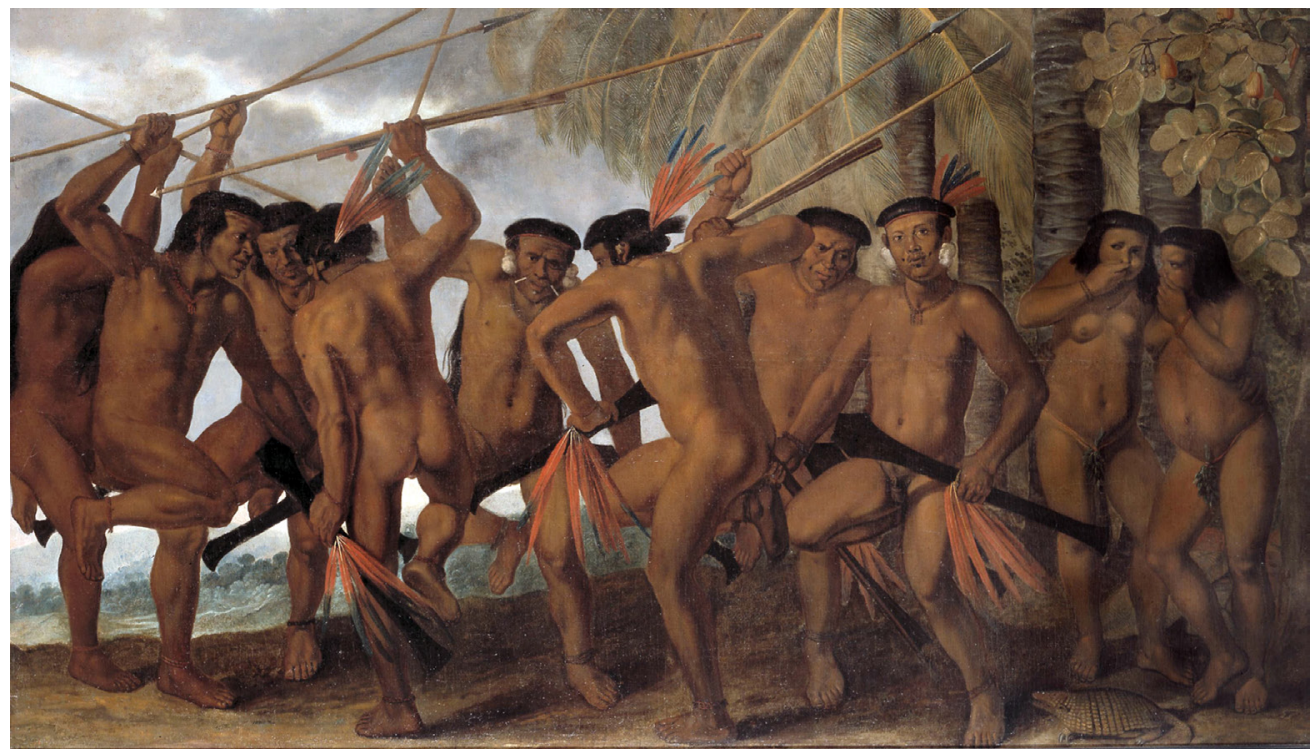

Figura 6 - Dança dos Tarairiu (Tapuias). Fonte: <https:/ /bit.ly/3dS l ucl>.

A correspondência missionária também apresenta relatos de grande visualidade, como a do padre Andreoni, que na mesma carta de 1706 descreve os tapuias Janduin de modo especulativo, sem se render a um exotismo puro e simples:

Vieram ter conosco os Janduins, inteiramente nus e com os membros pintados de diversas cores, tiradas do suco de ervas e frutas, com os beiços, bochechas e orelhas furadas e nestes orifícios uns paus que ao falar se movem, subindo e baixando. ${ }^{24}$

A pintura foi associada no catálogo do Museu de Belas Artes à "Escola Portuguesa do século XVIII", que, por ser ligada à tradição pictórica tridentina, evidente na "morte alegórica e culta do Padre Bourel", interditava a pura fruição estética da imagem. Como a tela do padre apresenta uma paisagem em toda sua parte superior, ela foi tomada como uma exceção dessa escola de pintura. Svetlana Alpers, em A arte de descrever, examinou a maneira própria do olhar nas diferentes culturas, criticando o padrão homogeneizador difundido na Renascença pelo arquiteto renascentista Leon Battista Alberti (1404-1472), que funcionou como doutrina e foi praticado na academia. Esse padrão fundou uma arte narrativa para a história da arte: o quadro é o cenário no qual figuras humanas representam ações que enviam à fruição de imagens expressivas - a ut pictura poesis -, sejam da cultura clássica greco-romana, sejam da Verdade das Escrituras sagradas. Nela os personagens são sempre signos e os quadros 
são como janelas. Mas esse padrão não dava conta do que era próprio da arte holandesa. A nova linguagem que encontraram no século XVII se opôs justamente às formas narrativas de representação do mundo que tinham como base os textos verbais, constituindo-se assim como uma cultura especificamente visual: descrevem com detalhe e naturalidade, sem alegorias na interpretação do material visual. As lições de moral estão na superfície do quadro, são descritivas. Ainda que a descrição seja algo evidente em qualquer narração figurativa e que esteja presente em artistas europeus dos séculos XVII e XIX, como Caravaggio, Velázquez, Vermeer e Manet, ela está sujeita aos postulados da pintura narrativa-prescritiva. ${ }^{25}$

Vemos o impacto dessas considerações no estudo sobre a retórica do Império espanhol na América, de Luisa Elena Alcalá. Explorando imagens que escapam à hierarquia da alta cultura e aquelas envolvidas com a tradição generalizada de emblemas, a autora adverte sobre o uso da fórmula da paisagem flamenga, pintura descritiva que se difundia desde o século XVI e que no final do XVIII havia se estabelecido como padrão de apresentação também no mundo católico, tendo a paisagem como pano de fundo para cenas figurativas e narrativas. Do mesmo modo, na Europa protestante a imagem sagrada continuou mantendo uma vigência, de maneira que se costuma inserir uma figura narrativa na cena em um dos cantos inferiores da tela, modelo exportado massivamente para o Novo Mundo. ${ }^{26}$

As cenas de cotidianidade da tela são um exemplo dessa mistura de pintura descritiva e narrativa. $\bigcirc$ conjunto da representação está euforizado, reiterando uma cotidianidade pacífica, apenas interrompida pela cena dolorosa. Na parte inferior da cena vemos índios trabalhando, boizinhos pastando, árvores vicejando e aves silvestres revoando, provocando uma integração amorosa. Os corpos evocados nesse cotidiano estão em seus labores, encenando algum momento de paz ocorrido ao longo dos dez anos da missão de Bourel: plantar, colher, pescar, pastorear, fazer adornos e acessórios de penas, tecer os panos de algodão, moquear o peixe, amar, rezar. É uma pintura realista. Não há nada sobrenatural. Nem anjos, nem indígenas demonizados.

$\bigcirc$ protagonismo da paisagem se manifesta na metade superior da tela, parecendo expandir-se pelas laterais. $\bigcirc$ reino mineral se realiza em serras, serrotes, pedras, águas, furnas. Serra do Apodi, da Ibiapaba, da Borborema, ou alguma serra renana? As massas de água, além de refletirem a cena a partir da parte inferior da tela, expressam preocupações políticas e comunicam lugares biográficos, irônica abundância em uma região sujeita a secas. Schama encontrou em uma literatura fluvial de fins do século XV um sentido sagrado e vital para as confluências 
27. Schama (1996, p. 268272).

28. Dainville (1969). de águas, como a circulação do sangue pelo corpo. Como geografia sagrada, ocupava-se em saber qual seria o correspondente ao rio Nilo, um dos quatro braços em que se dividiu o rio primordial ao deixar o Éden, segundo o Gênesis 2:13. Na tela, seria o rio Paraíba um outro Niloẹ27 O rio Paraíba, que está ao pé da tela e que mana de uma furna iluminada ou de uma cachoeira, poderia ser referência ao rio primordial que alimentaria o Atlântico, considerando que o espaço em que morre o padre se conforma como uma itha, cercada por três águas?

A descrição de Olavo de Medeiros Filho da tela, incluída no livro de Válter Guerra, reafirma que toda descrição de uma imagem encerra uma boa dose de explicação. Nesse caso, trata-se da definição da matéria específica de que era feita a palha na qual se recostava o padre Bourel - "uma rústica cabana coberta de buriti", a identificação da vegetação nativa - das palmáceas ou catolés, das aves como "belas araras cortando o céu apodiense" ou das "serras azuladas", como próprias da realidade ecológica da região do Apodi, que projeta também um aspecto identitário, certamente não previsto pelo pintor anônimo. Alguns elementos da figuração podem ser associados ao Apodi. A chapada do Apodi pode efetivamente ser uma das serras representadas na paisagem. As palmeiras da pintura se assemelham aos catolés (Syagrus oleracea), que ocorre em abundância na vegetação de caatinga e que predomina no Apodi, assim como os cactos, planta tipicamente americana, já presente em Tenochtitlán, "lugar dos cactos sagrados", ou representado na arte do povo Moche do antigo Peru, além de uma das plantas que Cristóvão Colombo levou para Europa, a Tacinga palmadora, ou Palmatória, também conhecida como quipá, algo que, aliás, por se remeter ao tradicional solidéu judaico, alimentaria a busca de evidências de uma cultura criptojudaica nos sertões do Nordeste brasileiro. No entanto, embora a paisagem da pintura possa transmitir uma suposta semelhança com a geografia local - as margens do lago Apodi ou sua serra ao fundo -, ela não tem desejo de verdade geográfica. Os jesuítas são apontados, por conta da profusão e precisão de seus relatos de missões ultramarinas, como os fundadores da ciência geográfica, de modo que não se trataria de um mapa malfeito. ${ }^{28}$ As ideias territoriais, políticas e religiosas da retórica visual em torno da morte do padre são expressivas da vizinhança de derrota do projeto missionário na América portuguesa, mesmo tendo sido a vanguarda da Contrarreforma e aplicado a política da monarquia portuguesa.

A cena pacífica pode ter sido inspirada em duas relações missionárias, tal como vemos nos seguintes fragmentos. Na carta do padre Francisco de Matos, de 1701 
[...] enfim se alcançou para as Aldeias dos Índios terras suficientes para poderem cultivar sem serem molestados pelo gado dos curraleiros. [...] a algumas léguas dos soldados da Casa Forte, a conveniente distância, para não serem injustamente vexados por eles, ávidos da liberdade alheia. [...] trazem á mansidão cristã a sua ingênita fereza. [...] pela alacridade com que os Índios constróem as suas casas como que à compita; na facilidade com que aprendem de cor as orações; na pontualidade com que cada dia vêm à Igreja de manhã e de tarde; na alegria que mostram quando levam à fonte do batismo, os seus filhos. ${ }^{29}$

Na carta do padre João Antônio Andreoni, de 1706:

[...] já começam a amansar pouco a pouco. Os casados já dormem em suas barracas, os mais no chão, que é a enxerga dos cansados, ao pé do fogo aceso. Vêm à lgreja, de mãos postas e erguidas, adoram a Deus, que fez o céu e a terra; confessam ao Senhor de tudo; assistem em silêncio ao Santo Sacrifício; batem no peito; ouvem os avisos; e obedecem armados de arco e frechas, mas com o arco em repouso. ${ }^{30}$

Qual o lugar desse locus amenus praticado pelos jesuítas, leitores dos clássicos, frequentadores de pomares e hortas dos colégios da companhia que evocavam o velho tópico do jardim de delícias, observado por Evaldo Cabral de

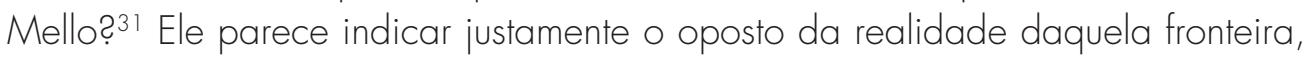
um paroxismo: uma cena pacífica em um lugar de violência constante. Será que o pintor estaria monumentalizando a rede com o objetivo de intrigar a cena cotidiana de uma aldeia de indígenas pacificados e felizes? Será que o inusitado de seu posicionamento em tão grande altura teria desejado provocar um destaque visual, um relevo que, identificado por meio de associações, enigma outra vez, possibilitaria uma leitura dupla: "aqui está assim, mas normalmente é o contrário". $\bigcirc$ pintor trataria de posicionar essa cotidianidade no movimento "entre": entre o baixar das aves e o subir das palmeiras, tudo pode mudar.

Sua apresentação como iconotexto, oferecendo-se a uma leitura simultânea, embora diferenciada, do espectador, o desafio de ler a imagem e olhar a palavra implicada (da cena ao subscrito, dele à cena outra vez), as indicações numéricas que guiam o espectador e o intrigante espaço comprimido e impossível demonstram que a imagem quer deixar-se ver como cifrada e, portanto, aberta à leitura simbólica, atestando com isso seu caráter enigmático. $\bigcirc$ tema biográfico denuncia sua propriedade como arte da memória, abarcando na biografia um espaço político e geográfico e realizando uma "composição vendo o lugar", variação pictórica do exercício mental que Inácio de Loiola denominava "composição de lugar": provocar imagens mentais realistas, emotivas e plásticas, definidas com precisão llongitude, largura, tipo de terreno, personagens com seus trajes e
29. Leite, op. cit., p. 374

30. Ibid., p. 376.

31. Mello (1999) 
32. A tradição emblemática esteve no século XIX restrita à coleção de curiosidades dos antigos, renovando-se o interesse por seu estudo entre as décadas de 1940-1960. Apesar do raro que possa parecer esse tipo de imagens e seus usos, elas estão integradas na cultura contemporânea, seja nos mecanismos da linguagem publicitária ou na cena virtual contemporânea (LEAL; AMARAL JR., 2016; OLIVEIRA, 2014; OLLERO-LOBATO, 2014; RODRÍGUEZ DE LA FLOR, 1989; SANTOS, 2015).

33. Praz (1946, p. 226 apud COLI, 2009, p. 126). situações), conduzidas por meio de pequenas narrativas evangélicas. Esse conjunto evidencia seu pertencimento à tradição emblemática.

Os emblemas, também conhecidos como "empresa" ou "divisa", são uma das fontes de "invenção" da retórica clássica (história, apologias e parábolas, adágios, hieróglifos e emblemas) e gênero ponte entre literatura e arte. Eram populares na cultura da elite europeia entre os séculos XVI e XVIII, dando sentido a eventos públicos, evidenciando seu uso como linguagem específica do poder. ${ }^{32}$

A tela da morte de Bourel se adapta ao modelo clássico e geral de emblema (ou hieróglifo, que seria sua expressão eclesiástica), cujo conjunto deveria apresentar um sentido oculto moral que, junto do efeito poético, ajudaria os observadores que dominassem aqueles códigos a decifrá-lo. Assim, a pictura seria o conjunto da cena pintada; o inscriptio, o título da obra - Morte do padre...; e o subscrito, o texto explicativo no canto inferior direito. Se não se parece com um epigrama, guarda certo acento poético, especialmente no final: "em [seu] leito, cabana, embarcação de Brasileiros".

Mas a pintura seria uma variação de emblema. A emblemática, embora associada a uma proposta de raiz ética, levava à fruição de imagens da cultura clássica greco-romana e, portanto, pagã, e era ética alheia à transcendência ou à teleologia, tal como demonstram os emblemas clássicos do Emblematum Liber, de Andrea Alciato (Augsburg: Steyner, 1531), texto fundante dessa tradição, ou o livro Iconología, de Cesare Ripa, escrito em 1593, que teria colocado pela primeira vez o problema da interpretação das mensagens que se supunha existir nas imagens, entendendo que davam acesso a uma compreensão do espírito humano. Embora desde a Idade Média essa simbologia fosse aplicada na representação dos santos e de seus atributos (a concha de vieira de São Tiago, a roda de Santa Catarina, o passarinho de São Francisco etc.), na época moderna isso recebe um tratamento teológico.

Jorge Coli aponta a conexão entre a pintura do padre Bourel e a iconomística, programa teórico que fundamenta a singularidade da retórica visual jesuítica, tal como vemos na referência de Mario Praz (1896-1982), crítico de arte e literatura italiano, em seu Studi sul concettismo, de 1946: "Delle imagini che insegnano 'profitabilment, vivement e délicieusement' i misteri della Fede, i Gesuiti fecero addirittura una scienza. 'Iconomistica' la defini il gesuita tedesco Jakob Masen [...]".33

Jacob Masen (1606-1681) foi um intelectual da Companhia de Jesus, escritor de poemas e pequenos dramas, trabalhos de história e teologia, professor de arte e filosofia, poesia e retórica, chegando a propor para a eleição imperial em Frankfurt, em 1658, um texto de concórdia no âmbito dos conflitos religiosos 
na Alemanha, a Reconciliação bem considerada dos protestantes com os católicos. Ao longo de 1.122 páginas em in-oitavo de seu livro Speculum imaginum veritatis occultae, publicado em Colônia em 1650, ele apresenta em ordem alfabética o significado de diversas abstrações, como deuses, povos, valores morais, fábulas, rios, ventos etc., recuperando a cultura clássica e as novidades do mundo, espécie de enciclopédia destinada ao uso escolar universitário e útil como instrumento prático e rápido para compor e interpretar conteúdo alegórico ou simbólico em paredes, tetos, inscrições, símbolos ou brasões, ou seja, compor emblemas. Enquanto iconomística, constituiu-se como objeto de uma ciência. $\bigcirc$ título (Espelho de imagem da verdade oculta) pretende comunicar que, assim como o espelho reflete a natureza exterior, o símbolo reflete a natureza interior, como uma linguagem gestual da mente apreendida da natureza, inspirada na Carta de Paulo aos Coríntios, 13:12: "Videmus nunc per speculum in aenigmate". ${ }^{34} \mathrm{Na}$ breve introdução do livro ele define as "magníficas formações da criação" como uma linguagem divina, já presente nas Escrituras, mas ainda não nas imagens. Apresenta questões como: o homem seria capaz de reconhecer Deus, os anjos, a alma, as coisas espirituais em geral, através de imagens? Ou: Deus e os anjos revelam ao homem a natureza das coisas espirituais? $\bigcirc$ estudo sobre emblemas de Rodríguez de la Flor especializa esse processo ao localizar no coração da ldade Moderna a capitalização desse gênero por parte da instituição eclesiástica, rompendo com o caráter oracular da emblemática renascentista, colocando o gênero a serviço de uma vida religiosa, reconvertendo-a em "língua em que o próprio Deus se expressa ou na que, ao menos, pode ficar impressa sua lei, sua legislação". ${ }^{35}$

Isso também explicaria os procedimentos que levaram a tradição emblemática a se integrar à pintura, como parece ser o caso dessa tela, eliminando com isso o caráter de objeto efêmero ao qual a tradição emblemática estava ligada. Considere-se aqui o lugar central da pintura na tradição moderna, tida como a forma mais convincente de persuasão para internalizar uma leitura piedosa e mobilizadora de afetos, uma maneira de somatizar a imagem. Trata-se do argumento que separa Renascimento e Barroco em relação à pintura: dignificar a fruição das formas belas por sua eficácia pedagógica em comunicar a verdade das escrituras sagradas; a ut pictura poesis dos clássicos se realiza então como Theatrum Sacrum.
34. Scheid (1898, p. 8-11) e Masen (1650).

35. Rodríguez de la Flor (1995, p. 344-345). 
36. Cf. Lissovsky (2014) e Mauad (2018).

37. Alcalá (1998).

38. Appadurai (2008, p. 7). 39. Kopytoff (2008, p. 89).

\section{PERCURSOS}

Uma série de autores e obras que vêm constituindo o campo dos estudos visuais conferiram forte consistência teórica à abordagem biográfica. $\bigcirc$ conceito de memória póstuma das imagens desenvolvido no método iconológico de Aby Warburg, a Nachleben, e sua recepção desde os anos 1970, têm tomado o conceito de tradição a partir do que nela está implicado como movimento e trânsito. Nessa linha, os estudos visuais têm advertido sobre a importância do olhar antropológico para a percepção do modo como as culturas recebem as imagens, afirmando assim a visualidade e seu trânsito na cultura e discutindo certos fundamentos que têm orientado o modo como olhamos para o mundo e para a realidade nele implicada. Isso se evidencia tanto nos trabalhos que abordam imagens contemporâneas como no trato de fotografias, ${ }^{36}$ por exemplo nas imagens propagandísticas da conquista ibérica que se difundem na Idade Moderna, como tratado por Luisa Elena Alcalá ${ }^{37}$ Explorando o aspecto material da pintura como um bem de consumo, Arjun Appadurai sugere uma nova perspectiva sobre a circulação de mercadorias na vida social ao propor concentrar-se nas coisas trocadas e nos significados inscritos em suas trajetórias e usos, em vez de apenas nas formas e funções da troca (que seriam, em síntese, no caso da tela do padre Bourel, suas características barrocas e especificamente devocionais), em um esforço de desconstruir a imagem das coisas como estáticas ou imutáveis. É justamente nesse aspecto de "coisa trocada" que existe uma economia moral que precede a constituição de algo como mercadoria e na qual a tela informa suas possibilidades de trânsito e permanência, tal como expresso em seu resgate como memória cultural e política. ${ }^{38}$

Igor Kopytoff ${ }^{39}$ destacou a biografia de um objeto como estratégia de abordagem de sua vida social, dos valores de uso anexados ao objeto, mnemônicos ou pessoais, que nunca são simplesmente a venda, mas as negociações sociais e culturais em que ele está envolvido. Sua observação da vida de um objeto dentro e fora do estado de mercadoria é algo imediatamente aplicável à tela do padre, uma vez que ela se integra como bem de consumo no mercado de objetos devotos, mas adquire novos usos e significados em seu trânsito, evidenciando a produção de mercadorias como processo cognitivo e cultural, e não apenas como coisas produzidas. O autor faz uma alusão concreta aos destinos de pinturas que acabam em coleções particulares ou porões de museus, expatriadas de seus lugares e países de origem, exatamente como o caso desse anônimo. A observação antropológica permitiu notar como mudam os usos das coisas conforme o contexto de posse em que se encontram ou conforme o uso particular que se faz dela. As forças da mercantilização e da singularização levam à questão identitária envolvida no percurso dessa tela pelo 
mundo: o grupo que a singulariza concede aprovação coletiva e sacralidade cultural. Hans Hahn reitera a biografia das imagens como uma abordagem que dá conta dessa mobilidade do objeto e de sua transformação nesse processo, pois reconhece que sua existência ocorre em meio a muitos contextos que mudam seus papéis, usos e significados, e nos quais assumem um significado específico. Sua preferência pelo termo "itinerários" quer dar conta do caráter não linear de seu percurso. ${ }^{40}$ É desse modo que um quadro definido por seu pertencimento às belas artes é recebido em outro contexto de tradição. A ideia de peregrinação, no caso de nossa tela, é ainda mais precisa, diante de sua característica de imagem devota.

Assim, quem teria sido seu pintor e qual sua relação com o local que representa? Teria conhecido pessoalmente a região ou consultado os documentos internos produzidos pela Ordem? Jorge Coli advertia para a possibilidade de ter existido a prática interna de registros picturais nas missões, mas nada foi localizado no arquivo da ordem, de modo que seria improvável encontrar a autoria da tela em um dos companheiros de missão do padre Bourel. Mas certamente foram os protocolos de escrita jesuítica e sua disponibilidade de dados que teriam orientado a composição da pintura, expressando o trânsito entre as palavras e as coisas, distribuindo a informação que vai da escrita de uma carta em uma missão no meio do mundo até sua recepção por um pintor, provavelmente europeu, que a toma como assunto. Dessa forma, a biografia da tela complementa o corpus documental da historiografia, fazendo com que a escrita ocupe um lugar acessório, invertendo assim a relação ilustrativa que o texto concede à imagem. ${ }^{41}$

A pintura teria sido encomendada no mercado de arte devota nos séculos XVII e XVIII, tal como indicam os estudos sobre o tema. $\bigcirc$ reinado de João V (1706-1750) é considerado o momento áureo de produção artística do Barroco metropolitano e colonial, prolongando-se pelos anos de Pedro $\mid 1$ (1 683-1706). Algumas circunstâncias da cultura portuguesa, como a Restauração de 1640, o nacionalismo que despontou dela, a internacionalização do gosto da Corte e a circulação de artistas, encomendas e abertura de novas casas editoriais, conectaram Portugal às tradições italiana e do classicismo francês. No mercado colonial houve uma produção local de quadros e uma circulação de artistas oriundos especialmente de Lisboa e do Minho (Braga e Guimarães) que iam para Salvador, Rio de Janeiro, Pernambuco e Minas Gerais. Antônio de Oliveira de Louredo, um pintor ativo em Lisboa entre 1698 e 1704, enviou para igrejas e palácios de Pernambuco carregamentos de pinturas para aí serem vendidas, deixando sempre aberta a possibilidade de descobrir pinturas anônimas da época barroca desses artistas lisboetas enviadas para o Brasil, como a tela do padre Bourel, "meio esquecidas, em esconsas sacristias e dependências de igrejas e capelas, ou em depósito de museus e coleções privadas". ${ }^{42}$ 
43. Cf. Alcalá (2007) e Joaquim (2014).

44. Alcalá (2007).
Na província do Brasil e na vice-província do Maranhão, a circulação se materializou na regularidade das encomendas de objetos sacros de Portugal para a colônia e em uma produção local de imagens decorrente da entrada da ordem no Brasil em 1549, mantendo-se até sua expulsão em 1759. Nos Inventários e Relações da Companhia de Jesus da província do Brasil e nos estudos sobre a província de Nova Espanha sobressai uma diversidade de encomendas: pinturas sobre tela, esculturas de vestir, frontais para altares e outras miudezas de devoção como medalhas, coroas, agnus deis, rosários, crucifixos, anéis, livros, gravuras, relicários, pintura de tecidos, altares e bandeiras com motivos de circunstância, emblemas, biografias e catecismos ilustrados, vendidas pelos cegos nas feiras, romarias e peregrinações, junto dos folhetos de cordel ou almanaques, em lojas ou por correio, abastecendo as crenças dos fiéis, ressaltando o cuidado para que fossem de alta qualidade artística e de grande refinamento. ${ }^{43}$ Circulavam no mercado de arte e no mercado editorial e eram consumidas com cada vez maior intensidade pelas instituições católicas (as diversas ordens religiosas, a estrutura eclesiástica, irmandades laicas, famílias aristocráticas e setores populares), que as destinavam a seus templos e espaços domésticos com fins ornamentais, curativos ou pedagógicos, apoiando a realização de exercícios espirituais e sendo utilizadas nas missões rurais europeias ou americanas.

Os protocolos gerais de produção das pinturas constavam de um encomendante dotado de recursos que escolhia um pintor de renome, fazia um levantamento do preço, negociava o modo de pagamento, a entrega da obra e a definição de prazos, além de aprovar os ensaios que o mestre apresentava e incluir a obrigação de que os principais painéis da encomenda fossem por ele realizadas, e não por membros de sua equipe. A Companhia de Jesus era encomendante dotada de recursos: atendia a necessidade de abastecimento de suas missões na África, América e Ásia, e possuía modelos próprios e autonomia artística nas escolhas, mantendo a seu lado artistas de muito prestígio. Em sua estrutura interna contava com os procuradores, responsáveis pela gestão burocrática dos negócios da ordem, que inclui o abastecimento de bens trazidos da Europa, necessários para manter a subsistência das missões; algo como "ir de compras por Europa", conforme o sugestivo conceito de Alcalá, mantendo a cúria dos jesuítas em Roma informada sobre os negócios da companhia. Assim, uma frota marítima própria, a isenção de impostos de que gozavam as ordens religiosas e seu papel em uma extensa rede de comunicação que fazia circular informações, pessoas e bens, colocava-a no dispositivo rede. ${ }^{44}$

Trała-se de uma encomenda que atendeu a uma demanda figurativa muito específica, realizada nos padrões da alta pintura, representando um missionário 
obscuro que morre em região remoła, mas expressiva do critério de homem santo da Companhia de Jesus. É evidente que isso significa criar uma memória da Companhia de Jesus e teria sido parte de uma grande encomenda litúrgica e devota para ornamentar as igrejas que vinham sendo erigidas com a expansão missionária. Seu autor teria trabalhado em um ateliê integrado a essa rede que fazia circular objetos devotos. Nos marcos da memória da ordem, há que se considerar a cada vez mais próxima derrota do projeto missionário: durante o período joanino - D. João V (17061750) - os jesuítas começam a perder o apoio monárquico, pois apesar de o rei ter tido três tutores jesuítas em seus primeiros anos no poder, ele os substituiu pelos oratorianos, algo que se agravou com a ascensão de D. José l (1750-1777), quando a posição dos jesuítas no reino muda sensivelmente.

Algumas hipóteses podem ser apresentadas sobre esse encomendante. Poderia ter sido um item na lista de compras de objetos de devoção encomendados a algum procurador atuante entre 1709 e 1757 (período provável de execução da tela) que possuísse alguma conexão com o padre Bourel e com as missões Tapuia. Alguns procuradores cobrem esse período e viveram o período da Guerra dos Bárbaros, mas não mantêm forte relação com Bourel, como o padre Andreoni, possível encomendante, autor do conhecido livro Cultura e opulência, de 1711 , sob o pseudônimo de Andre João Antonil, provincial entre 1706 e 1709, reitor do Colégio de Olinda e do Colégio da Bahia, visitador das missões dos Tapuia do Rio Grande e do Ceará enviado pelo padre Antônio Vieira e autor do necrológio do padre Bourel, feito em 1709, em agosto, pouco depois de sua morte.

Mas até aqui, trata-se apenas de uma memória da ordem ao evocar a missão de um modo geral, sem nenhum elemento entre esses nomes que ligasse o conjunto das referências da tela: umas construções que lembram um castelo europeu associadas aos Colégios de Olinda e da Bahia e aos sertões. A tela apresenta algumas evidências de que, para além de se referir à Companhia de Jesus de um modo geral, ela seja memória particular de alguns de seus membros, que de forma discreta e enigmática (deve-se recordar que a pintura é um emblema) imprimem na tela uma experiência comum levemente identitária; muito mais uma homenagem.

Outro provável encomendante da tela teria sido o padre João Ginzl (1660-1743), ou Guincel, como é tratado na correspondência pública, que possui uma relação especial com o padre Bourel. Qual teria sido o objetivo dessa encomenda, para além de uma memória institucional, ao evocar a vida e morte do padre alemão Felipe Bourel?

Bourel e o padre João Ginzl são da mesma geração. Felipe Bourel 1 6591709), como vimos, nasceu na Alemanha, em Colônia Agripina em agosto de 
45. A Companhia de Jesus está repartida em províncias e cada grupo de províncias, segundo critérios geográficos ou linguísticos, constitui uma assistência. Na companhia antiga existiram seis assistências: Itália, Portugal, Espanha, Alemanha, França e Polônia. A Assistência Alemã se estendia na Europa Central, durante os séculos XVII e XVIII, dos Países Baixos (Bélgica, Holanda e Luxemburgo) aos territórios atuais da Alemanha, Suíça, Áustria, Hungria, Eslováquia, República Checa, Polônia e Croácia, englobando em sua maior parte os reinos da dinastia Habsburgo.

46. Cf. Leite (2004a).
1659, filho de um conselheiro, Gabriel Bourel. Em 1676, com dezessete anos, iniciou os estudos na Companhia de Jesus em Trier. Ao concluílos, por volta de 1692, pediu a Missão do Brasil. Antes permaneceu um ano como professor de matemática na Universidade de Coimbra, fazendo em 1693 sua profissão solene. Ginzl nasceu em Chomoutov (Komotau), vila de Olomouc (Olmütz), na Boêmia (tesouro barroco da República Tcheca, localizada em sua parte oriental) em 1660, filho de André Ginzl e Regina Ginzlin. Entrou na Companhia em 1676, com dezesseis anos de idade e fez sua profissão solene em 1694, ano em que embarcou de Lisboa para o Brasil. Suas cidades de nascimento compunham a assistência alemã da Companhia de Jesus. ${ }^{45}$

Embarcaram de Lisboa para o Brasil com um ano de diferença: Bourel na $57^{\circ}$ expedição da companhia, chegando à Bahia em maio de 1693, e Ginzl na $58^{\circ}$, desembarcando em fevereiro de 1694, ambos com 34 anos $^{46}$ e atuando pelo Colégio da Bahia nas missões do rio São Francisco. Em 1696 os jesuítas foram expulsos dessas missões por conta dos conflitos com os senhores da famosa Casa da Torre de Francisco Dias de Ávila. Então, Bourel interrompe sua itinerância e se torna adjunto do mestre de noviços no Colégio da Bahia. Supõe-se que Ginzl tenha também assumido alguma função no colégio. Atendendo ao mestre de campo dos paulistas, Bourel e Ginzl saíram juntos na fragata dos padres, da Bahia para o Arraial do Assu, chegando em outubro de 1699 e atuando pelo sertão dos Tapuia entre Rio Grande, Ceará e Piauí.

Viveram também a querela relacionada às suspeitas da coroa portuguesa sobre estrangeiros que atuavam em cargos de mando nas instituições religiosas. $O$ contexto dessa restrição se relacionava à guerra de Portugal com a Espanha e com a França (Guerra da Sucessão da Espanha, 1701-1714) e seu impacto na questão de limites a norte e sul da colônia, como a tomada espanhola da Colônia do Sacramento em 1705 ou o saque dos franceses ao Rio de Janeiro em 1710, além dos conflitos ao norte com franceses e espanhóis, tornando suspeita sua circulação nas fronteiras. Dali vieram muitos outros padres no período pós-Guerra dos Trinta Anos e Paz de Westália, a pedido da rainha de Portugal, dona Maria Ana de Áustria. Alguns desses padres, com boa formação teológica, científica e jurídica, majoritariamente oriundos das possessões dos Habsburgo, eram formados em universidades da ltália e Alemanha para ałuarem principalmente nessas missões Tapuias em torno da serra da lbiapaba ou nas missões da Amazônia.

O problema, apesar de Inácio de Loiola tê-lo previsto nas Constituições da ordem, estabelecendo a regra de que "todos tenham especial amor aos estrangeiros e ninguém meta prática de guerras ou contendas entre nações com prejuízo da caridade", provocou uma forte querela interna nos quadros da Companhia de 
Jesus. ${ }^{47}$ Em 1694 havia 257 estrangeiros na lista da Companhia que em 1698 ocuparam os cargos principais do Colégio da Bahia, gerando um conflito que indicava que eles preferiam atuar nas cidades e não nas aldeias, e que seriam padres menos aptos para a catequese num clima tropical, razão pela qual costumavam dirigir-se às missões orientais; ou ainda que manifestavam uma diferença de mentalidade em relação aos latinos, como o caso do padre suíço Aloísio Conrado Pfeil, que considerou as aldeias do século XVII mais como "antros" do que residências humanas. Isso deixava transparecer duas categorias de jesuítas do Brasil: os dos colégios e os das aldeias. O padre Antônio Vieira, então no cargo de visitador do Brasil, enfrentou esse problema por volta de 1684: embora neutro em relação aos estrangeiros, apoiou a ideia de que o número de missionários portugueses ou lusobrasileiros deveria ser maior do que o de estrangeiros, e insistiu pela vinda de padres de Portugal. O padre João Antônio Andreoni, então secretário da província e mentor do grupo italiano, entrou em luta aberta com o padre Vieira. ${ }^{48}$ Esse foi justamente $\circ$ período em que Bourel e Ginzl atuavam nas missões Tapuia, levando a supor uma conexão entre a querela e a encomenda da tela por alguém ligado a essas missões.

A isso se soma outra identidade estrangeira: Jacob Masen (1606-1681), o teorizador da imagem e inventor da iconomística referido anteriormente. Masen nasceu na Alemanha, em Dahlem, no ducado de Jülich, e se educou no ginásio Tricoronatum, em Colônia, dirigido pelos jesuítas. Circulou muito pela área do Reno como professor de retórica e poesia entre 1633 e 1679 (Trier, Emerich, Colônia, Paderborn), falecendo em Colônia em 1681.49 Portanto, poderia ter se encontrado com o padre Bourel entre 1676, quando este começou os estudos em Trier, e 1681, ano de sua morte. Isto é, há aproximadamente um intervalo de cinco anos de uma possível convivência que, por caminhos obscuros, poderia ter ecoado na escolha do tema da pintura feita em alguma oficina.

Ginzl era homem de fronteiras e com capacidade de administração nas redes jesuíticas. Por isso estaria envolvido de algum modo na encomenda, aproveitando uma passagem por Lisboa em uma de suas gestões, de forma que podia estar em contato direto com o ateliê em que foi pintada, ou mesmo encomendado a tela a um procurador. Até 1706 Ginzl esteve entre os Tapuia. Dessas missões ele se deslocou para as missões do Ceará, fazendo-se muito presente, pelas defesas jurídicas que escreveu, como visitador das missões do Rio Grande e porta-voz nos conflitos nas aldeias. Foi reitor do Colégio de Olinda em 1717, e entre 1720 e 1725 esteve envolvido com a defesa da manutenção de Ibiapaba, no Ceará, como estado do Brasil, em vez do Maranhão e do Grão Pará, como se propunha, tendo ido à Lisboa nas duas ocasiões para gerir a demanda, uma delas em julho de 1721. Segundo o catálogo de 1722, ele estava
47. Id., 2004b, p. 34.

48. Ibid., p. 31-38.

49. Scheid, op. cit., p. 8-11. 
50. Cf. Serrão, op. cit.

51. Ibid., p. 183-184.

52. Ibid.

53. Antropólogo, investigador no Centro de Ciencias Humanas y Sociales del Consejo Superior de Investigaciones Científicas (CSIC), autor, entre vários títulos, de Religiosidad popular, imágenes vestideras (CEA GUTIÉRREZ, 1992). em Ibiapaba, onde ficou por quatro anos, seguindo para Aquiraz. Depois de várias gestões na corte de Lisboa, enquanto reinava D. João, consegue fundar um hospício (casa ou residência grande, com enfermaria geral para os missionários doentes ou idosos) e o Seminário de Latim e Humanidades, atendendo às capitanias do Ceará e Piauhy, tendo sido o superior em 1730. Por fim, outro elemento importante é que Ginzl foi o responsável pelo programa visual da lgreja Matriz de Viçosa, no Ceará. ${ }^{50}$ Construída em 1695 junto de alguns êxitos da política missionária, como a retomada da aldeia de lbiapaba em 1700 e a vinda de uma nova leva de missionários, ela atendia ao desejo de estabilidade, frequente nas consultas e petiç̃es dos moradores na câmara por sacerdotes e ornamentos para as igrejas. O forro dessa igreja foi pintado entre 1720 e 1730, com dedicação à Nossa Sra. da Assunção: apresenta um estilo chão com nove painéis que desenvolvem um complexo programa de iconografia das Quatro virtudes cardeais, das Três virtudes teologais e dos Cinco sentidos, com "elementos maneiristas como as representações ingênuas da fauna e da flora tropical, frutas e outros pormenores exóticos, de deliciosa factura", ${ }^{11}$ que o artista anônimo colocou no lugar dos ornatos de grottesche das fontes clássicas. Em 1727 há um pedido de doação de ornamentos feito pelo bispo de Pernambuco a D. João V: foi enviada uma lista de objetos litúrgicos e atestou-se que nesse ano a Igreja Matriz de Viçosa havia passado por obras recentes e se encontrava pronta para celebrar os cultos. ${ }^{52}$

Antonio Cea Gutiérrez, especialista em temas de iconografia religiosa, supõe que o programa de ornamentação da tela da morte de Bourel segue o modelo de representação da morte de São Francisco Xavier na praia de Goa quanto à composição da morte do justo, algo que os estudos consultados confirmam. ${ }^{53}$ Francisco de Xavier (1506-1552) correspondia ao modelo de santidade de uma igreja triunfante e militante. Fez parte do grupo pioneiro de jovens que veio a fundar a Companhia de Jesus em 1541 e foi tomado como modelo máximo de missionário graças às virtudes da abnegação, trabalho, conversão, milagres e martírio. Apóstolo do oriente e padroeiro universal das missões, foi beatificado pelo papa Paulo $V$ em 1619 e canonizado pelo papa Gregório XV em 1622, juntamente com Inácio de Loyola. As narrativas de sua vida e morte contam que esteve dez anos em missão de evangelização em regiões do Império Português no oriente. Apesar de sua intensa atividade entre Índia e Japão, desejava entrar em Pequim para iniciar missões na China. Em 1552 desembarcou na itha de Sanchoão (Shàngchuān), ao sul da província de Guangdong, nos confins da China. Enquanto tentava negociar sua entrada no país, foi acometido por febres e abandonado na ilha, passando seus últimos momentos, em 1552, em agonia, abrigado numa choupana. Não teve morte violenta, mas solitária, beatífica e serena: seu martírio foi morrer sem receber os 
últimos sacramentos, acompanhado apenas por um chinês convertido, Antônio de Santa Fé, e por outro jovem oriental, numa humilde esteira de vime, abraçado ao crucifixo que seu amigo Loyola the havia dado.

Sua iconografia narrativa foi definida com as telas de Andre Reinoso na sacristia da lgreja de São Roque, em 1619, três anos antes de sua santificação, em 1622, e teve muitas ressonâncias, com acréscimo de novos elementos pictóricos e iconográficos específicos, como o traje de peregrino, a presença de orientais, de anjos e de objetos como o crucifixo, o rosário, a flor de açucena, livros, dentre outros signos, muitos deles se remetendo ao Oriente. Foi pintada em óleos, afrescos, gravuras e desenhos que circulavam em livros e folhetos volantes ou ornando as igrejas dos jesuítas em Roma, Goa, México, Luanda, Lisboa ou Salvador. Em Salvador, onde nunca esteve, o santo é padroeiro da antiga capital do Estado do Brasil desde 1686. Existem variações em sua representação na Hungria e em parte da Europa Central do final do século XVII até o final do XVIII que interessam especialmente pelo fato de que Felipe Bourel e seu companheiro Ginzl são dali originários. ${ }^{54}$ No óleo de Reinoso (Figura 7) há um elemento significativo de comparação com a tela da morte de Bourel: uma paisagem marítima com o navio português que o desembarcou na ilha de Sanchoão, além da presença dos dois homens, provavelmente o chinês Antônio e o jovem oriental.

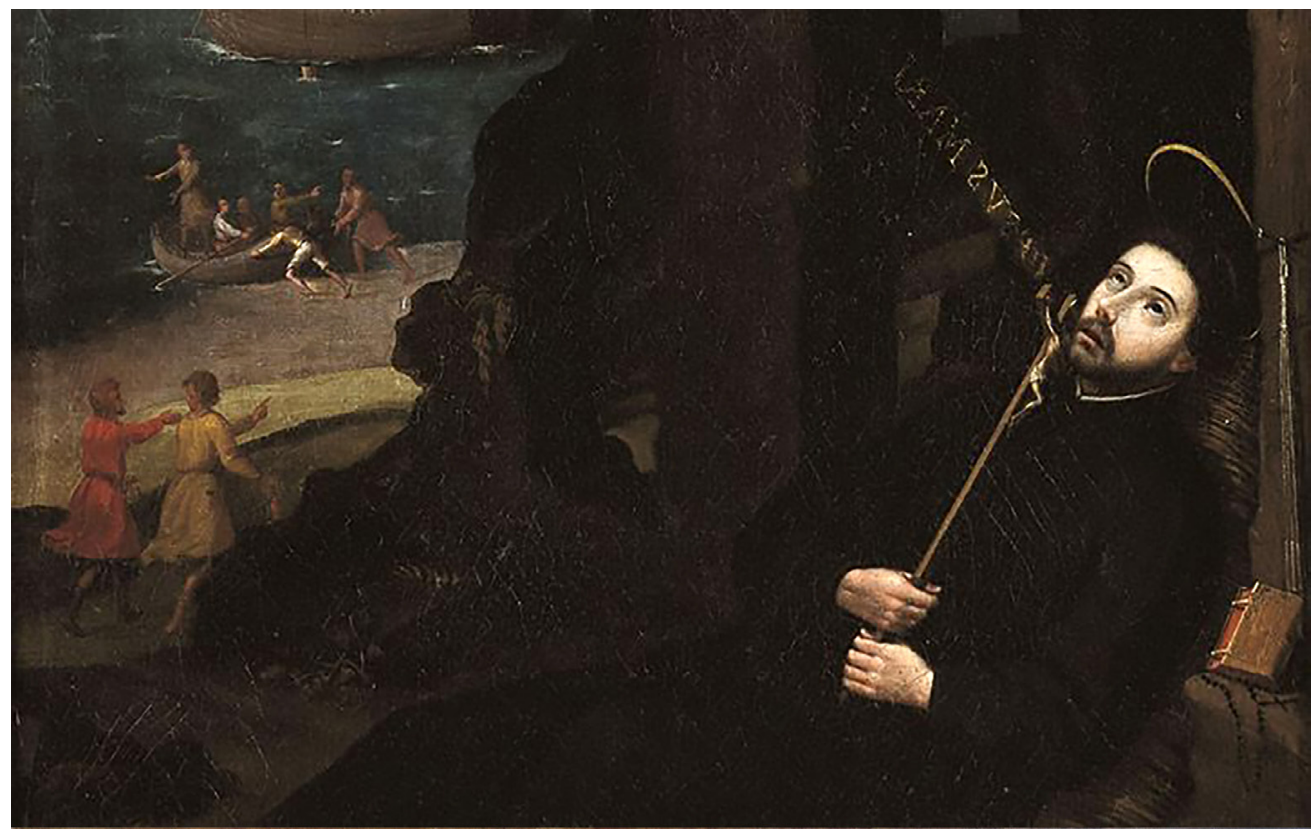

Figura 7 - André Reinoso. Morte de São Francisco Xavier. c. 1619. Detalhe. Óleo sobre tela, Sacristia da lgreja de S. Roque, Lisboa.
54. Cf. Lima (2014) e Serrão, op. cit. 
Diferentemente de pinturas de caráter propagandístico que desejavam atrair 56. Leite (2004a, p. 376, 2004b, p. 244). os favores reais, a tela de Bourel trata de exaltar membros virtuosos e suas vidas santas, refletindo um dos protocolos da escrita missionária. As ordens religiosas (jesuítas, franciscanos, carmelitas, oratorianos, capuchinhos, beneditinos) estabeleciam seus modelos próprios, mas, de modo geral, eles incidiam sobre os fundadores, colaboradores ou reformadores de suas ordens religiosas, além de místicos, os típicos bispos tridentinos, e missionários, como Francisco Xavier. Também já tinham uma iconografia bem estabelecida para gravuras e pinturas de religiosos pregando, batizando ou martirizados, preparados para aplicar uma potente política externa de canonização utilizando esse dispositivo racional de criação de fatos visuais. Era uma políitica eficiente em razão da quantidade de canonizações e do predomínio de santos jesuítas no século XVII: entre 1540 e 1770, 27 homens e cinco mulheres foram canonizados e seis foram beatificados pela lgreja. As duas novas ordens religiosas que se formaram com a Contrarreforma, jesuítas e capuchinhos, fizeram onze santos. Em 1622 houve a canonização simultânea de Santa Teresa, Santo Inácio, São Francisco Xavier e Santo Isidro Labrador. ${ }^{55}$

É nesse contexto que se estabelece a relação entre São Francisco Xavier e o santificável Filipe Bourel. A tela é um instrumento de propaganda da ordem e poderia visar sua canonização, tendo São Francisco Xavier como modelo. Os protocolos estabelecidos pela Congregação dos Ritos em 1588 para canonização de santos constavam de uma pesquisa da biografia individual e social do indivíduo, suas vicissitudes, sua morte exemplar e pedagógica, seus dons sobrenaturais e os sinais de uma predestinação, com testemunhos colhidos entre pessoas honradas, em geral membros da nobreza.

A que tipos comportamentais corresponde a tela? Do ponto de vista da memória da ordem jesuítica, consideremos a singularidade de Bourel enquanto missionário representativo da companhia, e em maior medida do que os demais companheiros com quem compartilhou as mesmas vicissitudes. Cartas do padre Andreoni, de 1706 e de 1709, contêm os dados da biografia de Bourel, apresentando-o como "Missionário decidido e pronto. Homem sábio e de vida santa que estava entre os matemáticos da Ordem", ou "[Bourel] era muito amado deles [dos paiacu] e viviam em comum [...], ainda que saíam alguns meses durante o ano a recolher frutos do mato". Bourel está entre os escritores da ordem compondo cartas, relações, certificados, defesas e apologias. A notícia de sua vida e morte está em De Vita et obitu P. Philippi Bourel Coloniensis et in Província Brasilica Missionarii, Vitae 51, 85-86.56

Antes de ir para as missões Tapuia, Bourel atuou no Colégio da Bahia, de onde fez expedições pelo sertão do Piauí, dirigiu uma aldeia de índios Rodela no rio São Francisco e demarcou com cruzes as terras designadas para lavoura dos 
índios, redistribuídas por ordem do governador geral do Brasil, D. João de Lencastro. $\bigcirc$ padre Miguel de Carvalho, que o acompanhou nesses caminhos, três anos mais tarde contou em sua Descrição que

eram 42 pessoas, e, embora sem matalotagem, nada lhes faltou enquanto caminharam uns 16 dias nas margens do Gurgueia; mas durante 5 dias que se afastaram dele, logo padeceram fome e teriam morrido, se os não salvara, por alturas do Rio Curimatã, uma grande abundância de ananases bravos, deliciosos no cheiro e no gosto, que foram a matalotagem de todos até chegarem a povoado. ${ }^{57}$

No ano seguinte, seu companheiro, o padre João Ginzl, atuou também em missões na aldeia de Zorobabé do São Francisco. Com exceção da consolação espiritual de que fruíam, foram muitas as vicissitudes. A impressão de isolamento vinha do caráter remoto do sertão do Apodi em relação ao Colégio da Bahia, base de sustento dessas missões: desde o Colégio da Bahia mais de trezentas léguas de espaço precariamente ocupado e informado. Nas palavras do padre Andreoni:

[...] as mais remotas aldeias, além do Rio Grande [...] é difícil visitar, mesmo deixando a aldeia do Lago Podi [...], nem podem ser alcançadas senão por via terrestre, tendo de se levar pelo sertão e catingas, a comida necessária, faltando às vezes a água. ${ }^{58}$

A informação da legenda da pintura, de que a missão do Apodi ficava "não muito longe de Olinda, Rio Paraíba", afora o fato de que provavelmente o pintor não tivesse a menor ideia das distâncias que figurava, corresponde às possibilidades reais e aos caminhos que a prodigiosa mobilidade dos missionários praticava. Enfrentavam ainda a hostilidade dessa sociedade de fronteira para com os Tapuia e com as missões, atualizando a oposição entre missionários e colonos, que pediam a destruição dos índios e das missões.

A tela representa a força institucional da ordem religiosa. No entanto, enquanto máquina de guerra, é frequentada por uma utopia. Como vida heroica, pode ser capitalizada por instituições de poder e seus processos de memória institucional, mas é também circunstância de aventuras espirituais, que sempre implicam desabrimento, abandono do ego, experiências de grande intensidade física e espiritual. Michel de Certeau, em A fábula mística, em relação à cisão causada por um pequeno grupo de jesuítas franceses por volta de 1630, que reivindicavam o retorno à mística da interioridade, a busca de Deus em si mesmo, aborda o problema daquilo que estava envolvido na decisão de organizar religiosos para a ação no mundo: em lugar de Deus 
59. Certeau (2006, p. 287289).

60. Cesáreo (1994, p. $185-$ 194).

61. Leite (2004a, p. 374) buscado na oração, a glória de Deus. Especialmente no contraste entre as duas tendências, sobressai-se a espécie de mística possível representada na decisão da Companhia de Jesus pela vida ativa. Os místicos radicais ganhavam interioridade, mas perdiam corporalidade. Por sua vez, ao escolher pela vida ativa perdia-se em interioridade, mas nela estava implicado um ganho de poder; poder que alinhado à dinâmica da modernidade tornou possível a existência do que o autor definiu como os "nômades", missionários que, estimulados pelo vigor institucional, se lançavam ao mundo. Gente como nosso padre Manuel de Morais, jesuíta que no século XVII se passou aos protestantes; ou os grandes itinerantes, como costumavam ser os jesuítas dedicados a missões - os grandes deslocamentos de Matteo Ricci até a China, ou esses padres que vieram da Europa central, como Bourel, Ginzl e tantos outros, integrados de algum modo ao Novo Mundo. Esses "nômades" apontam um horizonte para pensar a mística: "voltar a atravessar a mística, buscando não mais a linguagem que ela inventa para falar desse Uno ausente, tal como ansiavam os "espirituais" franceses do século XVIII, mas do corpo que fala na própria mística: o corpo social lou político), vivido (erótico ou patológico), escritural (como uma tatuagem bíblica), corpo narrativo (um relato de paixões), ou corpo poético (o corpo glorioso)". 59 Nas contingências do caráter individual e solitário da empresa evangelizadora as possibilidades de seu próprio corpo garantiam o êxito da empresa. Suas circunstâncias eram a distância do poder e das instituições metropolitanas, o pequeno número de missionários, as limitações econômicas, imensas distâncias a serem percorridas, debilidade física, excesso de trabalho, doenças, martírio e naufrágios. Ali, as instituições metropolitanas foram substituídas pela massiva presença da corporalidade do missionário que aparece, conforme o lindo trabalho de Mario Cesáreo, como "matéria protéica, adaptável e plástica, disposta a amoldar-se às novas circunstâncias e a constituir-se ela mesma, em instituição", tornando o corpo espaço simbólico. ${ }^{60}$ Essa itinerância apostólica é espiritual e, nesse sentido, percorre lugares por onde o padre andou, sacralizando o espaço com essa referência.

Os documentos de e sobre o padre Bourel refletem um envolvimento prático e interior com a realidade em que vivia. A situação em que é retratado na tela - o estado de martírio - evoca a melancolia, definida por Vitor Serrão como estado de alma usado como signo e símbolo de trauma, medo coletivo, postura social crítica, arrebatada espiritualidade, representativa das contradições do homem da Idade Moderna. O padre vive essa melancolia quando associa a missão do Apodi a exílio, purgatório e inferno, ou quando solicita aos superiores da ordem o retorno do noviço Alexandre Nunes, companheiro de missão retirado por melancolia. ${ }^{61}$

Os relatos também refletem uma espécie de conversão ideológica, passando do aborrecimento com os bárbaros à reprovação da barbaridade e da insensatez 
dos moradores, de forma a denunciá-la. Inicialmente Bourel compartilhava do mesmo ponto de vista que seus colegas das missões populares da Companhia de Jesus na Europa, evidenciando que a imagem de barbárie não era exclusiva ao mundo americano. Como o caso do padre Abarizcueta, que por volta de 1671 assim descrevia as missões das serras das Batuecas na Espanha: "Terra miserável, incapaz de cultivo [...] gente rústica, pouco menos que bárbara".62 Bourel, em carta de 1700, fala de umas seiscentas almas de índios "destituídos de razão, ou sem dela fazer uso": "[...] Paiacús, gênero de Tapuias bravos [...] Estes bárbaros são tão inclinados à desconfiança e tão mudáveis ao mais leve aceno de suspeita, por palavra ou obra, que desconfiam de amigos e de inimigos, e vagueiam pelos matos", e se espantava com seus costumes gentílicos, como o de comer os restos mortais de seus parentes reduzidos a pó, condimentados com mel silvestre.

Os jesuítas entraram apoiados pela força paramilitar representada pelo Terço dos Paulistas, mas a política de extermínio e a hostilidade dos moradores levou o padre à compaixão, tendo se tornado, ou sido recebido, como um crítico da lógica colonial, promovendo queixas e petições aos poderes da colônia sobre os moradores que compravam tapuias com armas e também vendiam armas aos tapuias no sertão. ${ }^{63}$ Uma carta do padre Andreoni, visitador dessas missões, dá conta do estado anímico dos índios e cria uma imagem de êxodo que une os corpos de índios e missionários como em uma peregrinação.

Com tal guerra torna-se estéril o território, fugiam as abelhas do mel, despojam-se os lagos menores do peixe, e as matas de caça. [...] Levando sustento consigo, viu-se obrigado o Padre a ir buscar os que estavam refugiados no sertão, com medo; e a acompanhá-los à volta, cheios de terror. [...], e a maior parte dos nossos Paiacus fugiram e vagueiam pelo sertão. [...] Não é fácil dizer o quão difícil foi achar quem quisesse receber com benevolência a esses Tapuias e quanto custou aos Missionários.

Ninguém os queria ter por vizinhos e os repeliam como a ladrões e revoltosos. [...] Como a transmigração se fazia do solo pátrio ou do sertão, começaram uns a dizer que iam como escravos, outros que iam a ser mortos pelos Paulistas, outros olhavam entre lágrimas o sertão que iam deixar, outros que não se poderiam defender dos contrários se fossem assaltados no caminho. Seguiram o Missionário apenas 200, [...] muitos atingidos de doença mortal, morreram, o que veio acender nos sobreviventes o desejo de voltar ao sertão. ${ }^{64}$

Rodríguez de la Flor, em ensaio sobre as ressonâncias de Murillo (1617-1682) na cultura visual contemporânea, apresenta uma compreensão sensível da expressão barroca que se relaciona à tela A morte do padre Bourel, especialmente a possibilidade de aplicar a noção de Pathosformel, de Aby Warburg, permitindo entender a força performativa do gesto de um padre que morre em uma cabana, quase só entre
62. Rodríguez de la Flor (1989, p. 54).

63. Lopes (2003, p. 513, 528).

64. Leite (2004a, p. 345) 
65. Cf. Lissovsky, op. cit. e Serrão (2016).

66. Rodríguez de la Flor (2019, p. 11-12).

67. Couto, op. cit., p. 350351. bárbaros. ${ }^{65}$ Nesse belíssimo ensaio, Rodriguez de la Flor propõe que a pintura de Murillo se abre ao espectador como um abraço maternal e feminino em razão de sua constância em figurar a fragilidade humana e a necessidade do outro: "sempre a 'santa pobreza', o bem-aventurado mundo da pobreza". 60 Mas, ao introduzir a alegria de viver nesse espaço de representação, desautoriza a desautorização do mundano.

Na tela, a figuração do padre em martírio evoca a figura da compaixão, mas com uma representação da pobreza que se dirige bem mais ao periférico, fronteiriçco e remoto. Embora não se expresse como abraço maternal, mantendo, ao contrário, o corpo masculino-trágico de Cristo, ela abre um lugar da guarda e do cuidado, que estaria ali na cabana em que o padre morre, agasalhado por poucos, mas amorosamente sentido pelos indígenas e por dois ocidentais. De algum modo a representação de momentos de paz na aldeia desautoriza a desautorização da cultura indígena, e nessas lonjuras é sensível à fragilidade humana e à necessidade do outro. Aqui também há, como em Murillo, a santa pobreza, o bem-aventurado mundo da pobreza. Assim, algo se redime nessa tela porque ao mesmo tempo que a lógica colonial tomou as missões como reserva de força de trabalho tornou-as também refúgio desses povos.

Em 1757 Bourel está entre os "varões ilustres em santidade" naturais de Pernambuco, ali colocado por Loreto Couto, já preparando a transição para o elogio dessa bondade como glorificação da aliança entre conquistadores, própria do século XIX e de sua construção do Estado-nação. À sua bondade Loreto Couto agregou dons proféticos, pressentindo a morte de seu companheiro, o padre Mauricio, sobre o qual não há referência na História da Companhia de Jesus no Brasil, de Serafim Leite. Descreve também a outra tela que retrata o padre Bourel. ${ }^{67}$

O venerável padre Felippe Bourel da Companhia de Jesus [...]. Foy para os índios exemplo e oraculo de santidade, [...] supre a excacez das notícias a excelência dos milagres, que obrou no tempo de sua vida, sendo singularíssimo o seguinte. Entrando na aldeia do Apody achou uha índia, que com lagrimas incomparáveis chorava a morte de hum seu filho, que falecera sem bautismo, e fora enterrado no campo. Lastimado o coração compassivo do servo de Deos desde lastimosos sucesso, e instado do poderoso instinto da caridade, rogou que desenterrassem o corpinho, e sendo assim executado, e trasido a sua presença, o recebeo nos braços, e pondo-se em oração, ressuscitou o menino, e depois de o bautizar o entregou a sua may, e foy Deos servido que sobrevivesse alguns dias, resultando deste prodígio gloria a majestade divina, grande opinião para o servo do Senhor, e edificação dos fieis. Este milagre se ve primorosamente retratado em hum quadro que se conserva na igreja da dita aldeã. Favorecido de Deos com espírito profético predisse cousas futuras [...]. Nos últimos anos praticou com maior desvelo as virtudes, que exercitara em toda a vida, ate que partio a receber o premio delas deixando de seu apostólico espirito gloriosa memoria. 
Este estudo pretendeu ser um exercício de aproximação da radicalidade da 69. Certeau, op. cit., p. 34 . 70. CONCÍlIO..., c2016. proposta dos estudos visuais em refletir sobre o olhar histórico projetado sobre as imagens, por meio do método biográfico de interpretação. ${ }^{68}$ De modo geral, destacamos a importância do movimento que mobilizou missionários para as fronteiras do Novo Mundo. A tela A morte do padre Felipe Bourel representa as periferias do Estado português, como foi a capitania do Rio Grande, e sai do circuito tradicional dos estudos barrocos, concentrados como são nas regiões centrais da América, como Minas Gerais ou Cuzco. Apresenta elementos de composição significativos da ação dos jesuítas nas fronteiras americanas, especialmente a relação indígenas-missionárioscolonos, de forte presença na fortuna crítica da historiografia brasileira. Comparado ao padrão de referência jesuítica em nossa historiografia, centrado nos padres Manuel da Nóbrega, José de Anchieta ou Antônio Vieira, ou aos grandes temas como são as missões Guarani ou as da Amazônia, a tela representa um tema periférico, mas central na retórica visual da Companhia de Jesus.

Nesse trânsito entre centro, periferia, margens e fronteiras, confluem índios, missionários e colonos, Colônia, Bahia e Olinda; serras da Borborema, do Apodi e da lbiapaba; nômades das aldeias e gestores nos Colégios; São Francisco Xavier morrendo em Goa e Bourel no Apodi. Há em tudo um forte ativismo no mundo, incorporando-os ao debate historiográfico. A ação missionária, independentemente do juízo que dela se faça em relação à conquista e integração dos povos ameríndios, constituiu um horizonte de observação entre mundos, por onde os jesuítas circularam com forte institucionalidade, tanto no alto poder das cortes europeias como em suas bases indígenas americanas, africanas e asiáticas, interceptando os grandes conflitos por terra e liberdade ocorridos nos sertões da América portuguesa. Na topografia ali representada se mostram "lugares de sofrimento e prova", tal como nos sugere Michel de Certeau ao tratar dos espaços de origem e destino desses missionários nômades. ${ }^{69}$ No entanto, pela via do processo de autorrepresentação da Ordem, a tela se torna identidade e salvação. Identidade porque proclama a vida santa associada a uma história concreta; salvação porque seus elementos indicam um modelo moral para os espectadores e alívio póstumo para o padre, que morre sem sacramento, mas cercado por seus afetos.

A retórica visual jesuítica tem forte presença na teoria da imagem. Decreto da XXV sessão do Concílio de Trento sobre "A invocação, veneração e Relíquias dos Santos, e das sagradas Imagens" tem sido apontado como um marco para a difusão de uma política da imagem em novos termos. ${ }^{70}$ A influência da Companhia de Jesus (1540-1773) na elaboração desses decretos tridentinos pode 
ser relativizada, mas em qualquer caso a instituição esteve na vanguarda desse movimento de reforma. De suas práticas espirituais e de seu envolvimento na produção de arte sagrada derivou uma teoria da imagem e a argumentação sobre a verdade que ela contém. Uma tendência da historiografia entende que as expectativas de resposta às imagens produzidas nesses documentos limitam-se à construção hagiográfica (abordando o problema apenas do ponto de vista da produção ideológica do catolicismo) ou à propagandística (nesse caso para os que entendem que há uma razão cínica operando todo o tempo na maquinação da instituição religiosa). Em suas renovações nos anos 1970, com a "virada pictórica", aponta para a historicidade das imagens: outras respostas que seriam consequência de seu trânsito pelo mundo e do mundo de significados para os quais se abriv em seu passo. Sua compreensão como sujeito - porque ao fim está suposto um poder proveniente da mensagem contida na tela - permitiu uma conexão com os fundamentos e problemas envolvidos tanto na história da arte quanto em sua continuidade crítica como estudos visuais.

A relação que estabelece entre Apodi e o mundo não se dá por veracidade geográfica, mas pelo poder de representação da ordem (honrando uma missão e um padre), que faz com que uma imagem repercuta tanto a tradição pictórica do Renascimento, do Barroco e dos diálogos entre pintura descritiva e narrativa, como as tensões violentas do período histórico em que foi gestada. A figuração do padre em martírio evoca a figura da compaixão que se dirige ao periférico, fronteiriço e remoto.

Por fim, a biografia da tela provoca uma reflexão sobre sua historicidade: seu trânsito pelo mundo, desde sua provável origem em uma oficina confessional até seu papel ornamental e devocional - essas pinacotecas das periferias do Império Português -, provavelmente compondo um lugar público para as famílias dos fazendeiros vitoriosos, que no século XVIII em suas recentes vilas, cidades ou arraiais do sertão compunham esse público desejoso de integração aos bens civilizados. Seu percurso parte de uma igreja para alguma casa-grande daquela sociedade sertaneja ou para alguém desse espaço maior que a tela abrange, entre Bahia e Alemanha, e daí para os circuitos de colecionadores e leilões de arte, circuitos de trocas, disponíveis ao público em museus e arquivos luso-brasileiros. Talvez seja o destino de muitas obras de arte, que refletem o caso do colecionador português, Eng. ${ }^{\circ}$ António Maria Fidié, filho do tenente-coronel João José da Cunha Fidié (falecido em 1856), que entre outras coisas, foi governador de armas no Piauí e na Paraíba, e cujo acervo veio parcialmente da extinção das ordens religiosas, particularmente do espólio da Companhia de Jesus. ${ }^{71}$ Assim, o tecido artístico da tela de Bourel é composto pelo artista anônimo, a oficina desconhecida, os clientes ligados a esse mundo confessional, os programas artísticos de tradição jesuítica, 
os públicos, índios e paroquianos das fronteiras coloniais e os fruidores, locais ou posteriores, como herdeiros ou compradores de obras de arte.

A análise iconológica da tela é tratada aqui como "detalhe", no sentido que the dá Omar Calabrese, de pertencer a uma totalidade. No entanto, nas "oscilações iconológicas" dos objetos, a tela também se realizou como fragmento, ${ }^{72}$ com uma cópia em acrílico de grande proporção que desde 2017 serve de palco e cenário dos festejos natalinos no município do Apodi, Rio Grande do Norte. É uma referência à tela original e recorda a tela inacessível, porque aprisionada nas câmaras refrigeradas do Museu Nacional de Belas Artes. Nela, nessa outra morte do padre, a pintura revive, revigorando com ela aspectos identitários que fortalecem a cultura local e as lutas dos descendentes indígenas do Apodi e de sua resistência histórica ao genocídio a que estiveram sujeitos seus antepassados. Uma fotografia em um livro de história transmite informações de natureza historiográfica mediadas por professores da escola e da universidade e os circuitos intelectuais locais que as integram, ali até onde alcancem. ${ }^{73}$
72. Calabrese (1987, p. 89).

73. Agradeço a Ezequiel Ludueña pela tradução da legenda, a Edrisi Fernandes pelas sugestões precisas e a Mauricio Lissovsky pela imersão nos estudos visuais. 


\section{REFERÊNCIAS}

LIVROS, ARTIGOS E TESES

ALCALÁ, Luisa Elena. A call to action: visual persuasion in a Spanish American painting. The Art Bulletin, London, v. 94, n. 4, p. 594-617, 2012. Doi: <https://doi.org/10.1080/00043079.2 012.10786061>.

ALCALÁ, Luisa Elena. De compras por Europa: procuradores jesuítas y cultura material en la Nueva España. Goya: Revista de Arte, Logroño, v. 318, p. 141-158, 2007.

ALCALÁ, Luisa Elena. Jesuits and the visual arts in New Spain, 1670-1763. New York: The Institute of Fine Arts: New York University, 1998.

ALCIATO, Andrea. Emblematum Liber. Augsburg: Heinrich Steyner, 1531.

ALPERS, Svetlana. El arte de describir: el arte holandés en el siglo XVII. Madrid: Hermann Blume, 1987.

APPADURAI, Arjun. A vida social das coisas: as mercadorias sob uma perspectiva cultural. Niterói: Editora da UFF, 2008.

ARARIPE, Tristão de Alencar. Cidades petrificadas e inscripções lapidares no Brazil. Revista Trismestral do Instituto Histórico e Geographico Brazileiro, Rio de Janeiro, t. 50, p. 213-294, 1887.

BURKE, Peter. Visto y no visto: el uso de la imagen como documento histórico. Barcelona: Crítica, 2001.

CALABRESE, Omar. La era neobarroca. Madrid: Cátedra, 1987.

CEA GUTIÉRREZ, Antonio. Religiosidad popular, imágenes vestideras. Zamora: Obra Cultural Caja España, 1982

CERTEAU, Michel de. La fábula mística (siglos XVI-XVII). Madrid: Siruela, 2006.

CESÁREO, Mario. Menu y emplazamientos de la corporalidad barroca. In: MORAÑA, Mabel (ed.). Relecturas del Barroco de Indias. Hanover: Ediciones del Norte, 1994. p. 185-194.

COLI, Jorge. Episódio e alegoria. Anuário do Museu Nacional de Belas Artes, Rio de Janeiro, v. 1, p. 105-128, 2009. Disponível em: <https://bit.ly/3es20NH>. Acesso em: 20 jun. 2020. 
CONCÍLIO, Ecumênico de Trento. Montfort Associação Cultural, São Paulo, c2016. Disponível em: <https://bit.ly/3vijwuD>. Acesso em: 17 jul. 2019.

COUTO, Dom Domingos do Loreto. Desagravos do Brasil e glórias de Pernambuco (1757). Rio de Janeiro: Tipographia da Bibliotheca Nacional, 1904.

DAINVILLE, François de. La géographie des humanistes. Genève: Slatkine, 1969.

GUERRA, Válter de Brito. Apodi, no passado e no presente. Apodi: Coleção Mossoroense, 1995.

HAHN, Hans Peter; WEISS, Hadas. Introduction: biographies, travels and itineraries of things. In: HAHN, Hans Peter; WEISS, Hadas (eds.). Mobility, meaning and the transformations of things: shifting contexts of material culture through time and space. Oxford: [s. n.], 2013. Disponível em: <https://bit.ly/32KCVrN>. Acesso em: 8 dez. 2020.

JOAQUIM, Mariana Alliatti. O ofício do procurador-geral das missões e a formação de redes sociais da Companhia de Jesus nas missões do Grão-Pará e Maranhão. Oficina do Historiador, Porto Alegre, p. 1813-1831, 2014.

KOPYTOFF, Igor. A biografia cultural de coisas: a mercantilização como processo. In: APPADURAI, Arjun. A vida social das coisas: as mercadorias sob uma perspectiva cultural. Niterói: Eduff, 2008. p. 89-121.

LEAL, Pedro Germano; AMARAL JR., Rubem (eds.). Emblems in colonial Ibero-America. Glasgow: Stirling Maxwell Centre, 2016.

LEITE, Serafim. História da Companhia de Jesus no Brasil. São Paulo: Loyola, 2004a. v. 5.

LEITE, Serafim. História da Companbia de Jesus no Brasil. São Paulo: Loyola, 2004b. v. 7.

LEITE, Serafim. História da Companbia de Jesus no Brasil. São Paulo: Loyola, 2004c. v. 8.

LIMA, Luís Filipe Silvério; SILVA, Bianca Carolina Pereira da. A presença do Novo Mundo na iconografia da morte e dos sonhos de São Francisco Xavier. Varia Historia, Belo Horizonte, v. 30, n. 53, p. 407-441, 2014. Doi: <https://doi.org/10.1590/S0104-87752014000200005>.

LISSOVSKY, Mauricio. A vida póstuma de Aby Warburg: por que seu pensamento seduz os pesquisadores contemporâneos da imagem? Boletim do Museu Paraense Emílio Goeldi: Ciências Humanas, Belém, v. 9, n. 2, p. 305-322, 2014. Doi: <http://dx.doi.org/10.1590/1981$81222014000200004>$.

LOCKHART, John; SCHWARTZ, Stuart. América Latina en la Edad Moderna: una historia de la América española y el Brasil coloniales. Madrid: Akal, 1992. 
LOPES, Fátima Martins. Índios, colonos e missionários na colonização da Capitania do Rio Grande do Norte. Mossoró: Fundação Vingt-un Rosado, 2003.

MARAVAlL, José Antonio. A cultura do barroco. São Paulo: Edusp, 1997.

MASEN, Jacob. Speculum imaginum veritatis occultae. Coloniae Ubiorum: Joannis Antonii Kinchii, 1650.

MAUAD, Ana Maria. A biografia política de uma fotografia. Jornal da Unicamp, Campinas, 20 abr. 2018. Disponível em: <https://bit.ly/3evr2eV>. Acesso em: 20 abr. 2019.

MEDEIROS FILHO, Olavo de. A morte do padre Filipe Bourel: descoberta a primeira pintura do Rio Grande do Norte. Tribuna do Norte, Natal, 24 out. 1993.

MEDEIROS FILHO, Olavo de. Os antigos cronistas e os rios Upanema, Apodi e Mossoró. Mossoró: Fundação Vingt-un Rosado, 1987.

MEDEIROS FILHO, Olavo de. Os índios do Açu e do Seridó. Brasília, DF: Editora do Senado, 1984.

MELLO, Evaldo Cabral de. À sombra dos coqueirais. Folha, [s. l.], 4 abr. 1999. Disponível em: <https://cutt.ly/KfTyTL5>. Acesso em: 4 jun. 2019.

MOREAU, Pierre; BARO, Roulox. História das últimas lutas no Brasil entre bolandeses e portugueses e relação da viagem ao país dos Tapuias. Belo Horizonte: Itatiaia, 1979.

MORGADO GARCÍA, Arturo. Historia de la cultura en la edad moderna. Cádiz: Universidad de Cádiz, 2019.

MOTT, Luiz. A Inquisição no Rio Grande do Norte. O Poti, Natal, 13 jul. 1986. Disponível em: <https://cutt.ly/TfTeVIh>. Acesso em: 17 jun. 2019.

MOTTA, Nonato. Notas sobre a Ribeira do Apody. Revista do IHGRN, Natal, v. 18-19, p. 45-90, 1920-1921.

OLIVEIRA, Carla Mary da Silva. A América alegorizada: imagens e visões do Novo Mundo na iconografia europeia dos séculos XVI a XVIII. João Pessoa: Editora da UFPB, 2014.

OLLERO-LOBATO, Francisco. De la ocasión a la alegoría: retratos, imágenes y fiestas tras la victoria de Viena de 1683. Quintana, Logroño, v. 13, p. 221-239, 2014.

PEREIRA, Joaquim. Memoria sobre a extrema fome e triste situação em que se achava o sertão da Ribeira do Apody da Capitania do Rio Grande do Norte. RIHGB, Rio de Janeiro, v. 20, p. 175-185, 1857. 
PESSOA, Ângelo Emílio da Silva. As ruínas da tradição: a Casa da Torre de Garcia d'Ávila. Família e propriedade no nordeste colonial. João Pessoa: Editora da UFPB, 2017.

PORTO, Maria Emilia Monteiro. Jesuítas na Capitania do Rio Grande, séc. XVI-XVIII: arcaicos e modernos. 2001. Tese (Doutorado em História) - Universidad de Salamanca, Salamanca, 2001.

PUNTONI, Pedro. A guerra dos bárbaros: povos indígenas e a colonização do sertão nordeste do Brasil, 1650-1720. São Paulo: Hucitec, 2000.

RIPA, Cesare. Iconologia overo descrittione dell'imagini universali cavate dall'Antichità et da altri luoghi. Roma: Heredi di Giovanni Gigliotti, 1593.

RODRÍGUEZ DE LA FLOR, Fernando. De las Batuecas a las Hurdes: fragmentos para una historia mítica de extremadura. Mérida: Regional de Extremadura, 1989.

RODRÍGUEZ DE LA FLOR, Fernando. Emblemas: lecturas de la imagen simbolica. Madrid: Alianza, 1995.

RODRÍGUEZ DE LA FLOR, Fernando. Espectros de Murillo. In: ROMERO, Pedro; MARTÍNEZMONTIEL, Luis; VÁZQUEZ, Joaquín (coord.). Aplicación Murillo: materialismo, charitas, populismo. Sevilla: Icas, 2019. p. 9-24.

SALMORAL, Manuel Lucena. Historia de Iberoamérica. Madrid: Cátedra, 1990. t. 2.

SANTOS, Luísa Ximenes. A palavra e a imagem: usos da emblemática na assistência portuguesa da Companhia de Jesus. 2015. Dissertação (Mestrado em História) - Universidade Federal de Pernambuco, 2015.

SCHAMA, Simon. Paisagem e memória. São Paulo: Companhia das Letras, 1996.

SCHEID, Nicolas. Der Jesuit Jakob Masen, ein Schulmann und Schrifsteller des 17 Jh. Köln: Commissions Verlag und Druck von J. P. Bachem, 1898.

SERRÃO, Vitor. Os programas imagéticos na arte barroca portuguesa: a influência dos modelos de Lisboa e a sua repercussão nos espaços luso-brasileiros. Boletim Cultural da Assembleia Distrital de Lisboa, Lisboa, t. 1, n. 95, p. 149-186, 2009.

SERRÃO, Vítor. A leitura micro-artística e a eficácia teórico-metodológica da nossa disciplina: "estudos de caso" na Idade Moderna portuguesa. In: FLOR, Pedro (coord.). Pensar história da arte: estudos em homenagem a José-Augusto França. Lisboa: Esfera do Caos, 2016. p. 59-80.

SOUZA, Alcídio Mafra. O Museu Nacional de Belas Artes. São Paulo: Banco Safra, 1985. 
SOUZA, Maria Eduarda Alves de. Duas mostras das novidades no Belas-Artes. Jornal do Brasil, [s. l.], v. 93, n. 87, p. 8, 1983.

Artigo apresentado em: 16/09/2020. Aprovado em: 19/02/2021.

\section{(c) BY}

All the contents of this journal, except where otherwise noted, is licensed under a Creative Commons Attribution License 